\title{
Analysis of the 5-HT ${ }_{1 \mathrm{~A}}$ receptor involvement in passive avoidance in the rat
}

\author{
${ }^{1,3}$ Ilga Misane, ${ }^{2}$ Christina Johansson \& ${ }^{1,4}$ Sven Ove Ögren
}

${ }^{1}$ Division of Cellular and Molecular Neurochemistry, Department of Neuroscience, Karolinska Institute, S-171 77 Stockholm and ${ }^{2}$ Astra Arcus AB, CNS Preclinical R\&D, 15185 Södertälje, Sweden

1 The effects of the 5- $\mathrm{HT}_{2 \mathrm{~A} / 2 \mathrm{C}}$ agonist $\mathrm{DOB}$, the selective 5- $\mathrm{HT}_{1 \mathrm{~A}}$ agonist $\mathrm{NDO} 008$ (3-dipropylamino5-hydroxychroman), and the two enantiomers of the selective 5- $\mathrm{HT}_{1 \mathrm{~A}}$ agonist 8 -OH-DPAT $(\mathrm{R}(+)-8-\mathrm{OH}-$ DPAT and $\mathrm{S}(-)-8-\mathrm{OH}-\mathrm{DPAT})$ were studied in a step-through passive avoidance (PA) test in the male rat.

2 The 5- $\mathrm{HT}_{1 \mathrm{~A}}$ agonists injected prior to training (conditioning) produced a dose-dependent impairment of PA retention when examined $24 \mathrm{~h}$ later. $\mathrm{R}(+)-8-\mathrm{OH}-\mathrm{DPAT}$ was four times more effective than $\mathrm{S}(-)$ 8-OH-DPAT to cause an impairment of PA retention. Both NDO 008 and the two enantiomers of 8OH-DPAT induced the serotonin syndrome at the dose range that produced inhibition of the PA response, thus, indicating activation of postsynaptic $5-\mathrm{HT}_{1 \mathrm{~A}}$ receptors.

3 Neither NDO 008 nor R(+)-8-OH-DPAT induced head-twitches, a behavioural response attributed to stimulation of postsynaptic $5-\mathrm{HT}_{2 \mathrm{~A}}$ receptors. In contrast, DOB induced head-twitches at the $0.01 \mathrm{mg} \mathrm{kg}^{-1}$ dose while a 200 times higher dose was required to produce a significant impairment of PA retention.

4 The impairment of PA retention induced by both NDO 008 and R(+)-8-OH-DPAT was fully blocked by the active $\mathrm{S}(+)$ - enantiomer of the selective 5-HT $\mathrm{HA}_{1 \mathrm{~A}}$ antagonist WAY 100135 and the mixed $5-\mathrm{HT}_{1 \mathrm{~A}} / \beta$-adrenoceptor antagonist $\mathrm{L}(-)$-alprenolol. In contrast, the mixed $5-\mathrm{HT}_{2 \mathrm{~A} / 2 \mathrm{C}}$ antagonists ketanserin and pirenperone were found to be ineffective. Moreover, the $\beta_{2}$-adrenoceptor antagonist ICI 118551, the $\beta_{1}$-antagonist metoprolol as well as the mixed $\beta$-adrenoceptor blocker $\mathrm{D}(+)$-alprenolol all failed to modify the deficit of PA retention by NDO 008 and R(+)-8-OH-DPAT. None of the 5-HT 1 or $5-\mathrm{HT}_{2 \mathrm{~A} / 2 \mathrm{C}}$ receptor antagonists tested or the $\beta$-blockers altered PA retention by themselves.

5 A 3 day pretreatment procedure $\left(200+100+100 \mathrm{mg} \mathrm{kg}^{-1}\right)$ with the tryptophan hydroxylase inhibitor p-chlorophenylalanine (PCPA) did not alter PA retention and did not prevent the inhibitory action of the 5-HT $\mathrm{HA}_{1 \mathrm{~A}}$ agonists, indicating that their effects on PA do not depend on endogenous 5-HT.

6 The effects of NDO 008 on PA were also studied using a state-dependent learning paradigm. NDO 008 was found to produce a disruption of PA when given either prior to training or retention or both prior to training and retention but it failed to affect PA retention when given immediately after training. 7 These findings indicate that the deficit of passive avoidance retention induced by the 5-HT $\mathrm{HA}_{1 \mathrm{~A}}$ agonists is mainly a result of stimulation of postsynaptic $5-\mathrm{HT}_{1 \mathrm{~A}}$ receptors but not $5-\mathrm{HT}_{2 \mathrm{~A}}$ receptors. The $5-\mathrm{HT}_{1 \mathrm{~A}}$ receptor stimulation appears to interfere with learning processes operating at both acquisition and retrieval.

Keywords: Passive avoidance; head-twitches; R(+)-8-OH-DPAT; S(-)-8-OH-DPAT; NDO 008; 5-HT IA $_{\text {receptors; 5-HT }}$ A receptors; $5-\mathrm{HT}_{2 \mathrm{C}}$ receptors; $\beta$-adrenoceptors

\section{Introduction}

At least 14 types of mammalian serotonin (5-HT) receptors have been isolated and classified into seven major families (5- $\mathrm{HT}_{1}$ to $\left.5-\mathrm{HT}_{7}\right)$ according to pharmacological, transductional and structural criteria (Hoyer et al., 1994; Hoyer \& Martin, 1997). In view of this receptor multiplicity, the potential role of the 5-HT receptor subtypes in behavioural and physiological functions has been studied extensively (Saxena, 1995; Villalon \& Terron, 1995).

Earlier studies showed that changes in serotonergic transmission in the brain could markedly modify aversive conditioning in the rat. For instance, treatments which increase serotonergic (5-HT) activity in the brain were reported to induce a marked impairment of active and passive

${ }^{3}$ Current address: Ilga Misane (Laboratory of Pharmacology, Latvian Institute of Organic Synthesis, Riga, Latvia) is a postdoctoral fellow at the Department of Neuroscience, Karolinska Institute.

${ }^{4}$ Author for correspondence at: Division of Cellular and Molecular Neurochemistry, Department of Neuroscience, Karolinska Institute, S-171 77 Stockholm, Sweden. avoidance (PA) learning (Ögren, 1982, 1985b, 1986a, b). The impairment of PA by p-chloroamphetamine (PCA) appeared to be related to 5-HT release and subsequent activation of 5$\mathrm{HT}_{1}$-like receptors but not 5- $\mathrm{HT}_{2}$-like receptors (Ögren, 1985b, 1986b).

The development of selective 5-HT ligands has made it possible to investigate the involvement of the $5-\mathrm{HT}_{1 \mathrm{~A}}$ receptor subtype in PA. The selective $5-\mathrm{HT}_{1 \mathrm{~A}}$ agonist $8-\mathrm{OH}-\mathrm{DPAT}$ given subcutaneously (s.c.) prior to PA training was found to produce a dose-dependent impairment of retention in the rat when examined 24 h later (Carli et al., 1992; Riekkinen, 1994).

Importantly, this impairment did not seem to be related to unspecific effects of 8-OH-DPAT on behavioural performance (Carli et al., 1992). However, it is noteworthy that the racemic form of 8-OH-DPAT has been used as the 'prototypical' agent in the investigation of $5-\mathrm{HT}_{1 \mathrm{~A}}$ receptors in most pharmacological studies. Relatively few studies have exploited the differences in the biological activities of the two enantiomers of 8-OH-DPAT, i.e. $\mathrm{R}(+)-8-\mathrm{OH}-\mathrm{DPAT}$ and $\mathrm{S}(-)-8-\mathrm{OH}-$ DPAT (Arvidsson et al., 1981, 1984; Hjorth et al., 1982). The 
enantiomers of 8-OH-DPAT have been reported to differ in their activities in a number of in vitro and in vivo assays, e.g. 5- $\mathrm{HT}_{1 \mathrm{~A}}$ and dopamine receptor binding studies (Björk et al., 1989; Lejeune et al., 1997), forskolin-stimulated adenylyl cyclase model (Cornfield et al., 1991; Foreman et al., 1995), inhibition of firing rate both in the dorsal raphe (Lejeune et al., 1997) and the CA3 area of the dorsal hippocampus (Hadrava et al., 1996), hypothermia (Björk et al., 1989; Hadrava et al., 1996; Yu et al., 1996) and PA (Jackson et al., 1994).

8-OH-DPAT which belongs to the chemical class of tetralins (Thorberg et al., 1987; Liu et al., 1993; Yu et al., 1993; Foreman et al., 1995; Lejeune et al., 1997) has been studied extensively because of its $5-\mathrm{HT}_{1 \mathrm{~A}}$ agonistic properties. Chroman derivatives have received much less attention, although in vitro studies have indicated that compounds like 5-MeO-DPAC and 5-OH-DPAC (also known as NDO 008) have high affinities and selectivity for $5-\mathrm{HT}_{1 \mathrm{~A}}$ receptors (Cossery et al., 1987; Thorberg et al., 1987). Little information exists on the in vivo activity of chromans including their behavioural effects. In this context, NDO 008 seems to be of particular interest as a pharmacological tool since it is chemically related to 8-OH-DPAT (NDO 008 is a monohydroxy derivative of 8-OH-DPAT) (Thorberg et al., 1987).

The objective of the present study was to examine further the involvement of $5-\mathrm{HT}_{1 \mathrm{~A}}$ receptor mechanisms in the regulation of the PA response in the rat. The effects of the two 5-HT ${ }_{1 \mathrm{~A}}$ agonists 8-OH-DPAT (8-hydroxy-2(di-n-propylamino)tetralin; $\mathrm{R}(+)$ - and $\mathrm{S}(-)$-enantiomers, respectively) (Arvidsson et al., 1981; Hjorth et al., 1982; Middlemiss \& Fozard, 1983; Hoyer et al., 1985) and NDO 008 (3dipropylamino-5-hydroxychroman) (Thorberg et al., 1987) were compared with those of the $5-\mathrm{HT}_{2 \mathrm{~A} / 2 \mathrm{C}}$ agonist DOB (1(4-bromo-2,5-dimethoxyphenyl)-2-aminopropane) (Glennon et al., 1984; Titeler et al., 1985; Titeler \& Lyon, 1987). In addition, the possible cointeraction of $5-\mathrm{HT}_{1 \mathrm{~A}}$ receptors and $\beta$ adrenoceptors in the modulation of PA behaviour was examined. To analyse whether the effects of the 5- $\mathrm{HT}_{1 \mathrm{~A}}$ agonists on PA were mediated via stimulation of pre- or postsynaptic receptors, the serotonin syndrome (Tricklebank et al., 1984; Berendsen et al., 1989; Blanchard et al., 1993) was scored in the PA procedure. In addition, we investigated if the effects of NDO 008 and $\mathrm{R}(+)-8-\mathrm{OH}-\mathrm{DPAT}$ were modulated by pretreatment with the 5-HT synthesis inhibitor pchlorophenylalanine (PCPA). To examine the involvement of $5-\mathrm{HT}_{2 \mathrm{~A}}$ versus $5-\mathrm{HT}_{1 \mathrm{~A}}$ receptors in the modulation of $\mathrm{PA}$ behaviour, the effectiveness of 5-HT agonists to induce headtwitches was tested, since this behavioural response is mediated via stimulation of the postsynaptic 5- $\mathrm{HT}_{2 \mathrm{~A}}$ receptors (Ögren et al., 1982; Peroutka \& Snyder, 1982). The possible involvement of state-dependent learning (Overton, 1966) in the PA retention was assessed using NDO 008.

Parts of this work have been presented in preliminary form at the 19th Annual Meeting of the European Brain and Behavioural Society, 1987 (Novi Sad, Yugoslavia) (Johansson et al., 1988).

\section{Methods}

\section{Animals}

Adult male Sprague-Dawley rats (B \& K UNIVERSAL AB, Sollentuna, Sweden) weighing $260-320 \mathrm{~g}$ were used in the passive avoidance studies and rats weighing $150-165 \mathrm{~g}$ in the head-twitch tests, respectively. The animals were allowed at least 1 week of adaptation in the standard maintenance facilities before the beginning of the experiments. The rats were housed in Macrolon ${ }^{\circledR}$ cages, each cage containing 2-6 animals and maintained at an ambient room temperature $\left(21 \pm 1^{\circ} \mathrm{C}\right)$. A $12 \mathrm{~h}$ light/dark schedule was used throughout the experiment and animals had free access to standard lab chow (Ewos R36, Ewos AB, Södertälje, Sweden) and tap water up to the time of the experiments. An habituation period of approximately $60 \mathrm{~min}$ to the environmental conditions of the experimental room always preceded any experimental procedure.

\section{Passive avoidance (PA) and behavioural observations}

PA was conducted as described in detail earlier (Ögren, 1985b; 1986a). Briefly, a modified shuttle-box with two communicating (sliding door built into the separating wall) compartments of equal size and a stainless steel bar floor was used. The right-hand compartment (shock compartment) was painted black to obtain a dark chamber. The left-hand compartment was illuminated by a bulb installed on the top plexiglass cover. The entire experiment was carried out by the same experimenter.

Training was conducted in a single session (day 1) during the light phase $(09: 00-16: 00 \mathrm{~h})$ of a $12 \mathrm{~h}$ day/night cycle. The animals ( $n=6-10$, for details, see Figure legends) were treated with the test compounds as described below. After the selected time interval following injection (day 1), rats were placed into the light compartment (with no access to the dark compartment) and allowed to explore for $3 \mathrm{~min}$.

During the exploration phase in the PA apparatus, the behaviour of the animals was assessed and the presence or absence of the components of the serotonin (5-HT) syndrome (flat body posture, lower lip retraction, reciprocal forepaw treading, head weaving, hind-limb abduction and tremor) (Tricklebank et al., 1984; Berendsen et al., 1989) and the rearing frequency were noted. A more detailed behavioural analysis was performed in the NDO 008 and DOB doseresponse studies. The serotonin (5-HT syndrome) was quantified using a ranked intensity scale where: $0=$ absent, $1=$ equivocal, $2=$ present, $3=$ intense. In these studies rearing was scored by counting the number of full rearings (move of the body through the vertical plane).

When 3 min expired, the sliding door was automatically opened by pressing a pedal and the rats were allowed to cross over into the dark compartment. Once the rats had entered the dark compartment with all four feet, the sliding door was automatically shut and an unescapable, constant current, scrambled shock $(5 \mathrm{~s}$ duration, $0.065 \mathrm{~W})$ was delivered through the grid floor. Latency to cross into the dark compartment (training latency) was recorded. Few rats failed to move into the dark compartment within $300 \mathrm{~s}$ (cut-off latency). In this case the door was reopened and the rats were gently moved by the experimenter into the dark compartment, where they received the foot-shock. After the shock, the rats were immediately removed from the PA apparatus.

Retention was tested $24 \mathrm{~h}$ later (day 2). The animals were placed into the light (safe) compartment, with access to the dark one (within $15 \mathrm{~s}$ ) for a period of $300 \mathrm{~s}$. The latency to cross into the dark compartment with all four feet was automatically measured (retention latency).

In most of the experiments, the drugs were injected prior to the training session. A separate experiment was designed to study the action of NDO 008 on PA retention in a statedependent learning paradigm. This paradigm was used since it is well established that the drug-state at training and testing can markedly influence retention performance in aversive learning tasks (Overton, 1966). Thus, the animal may only be 
able to retrieve the memory at the time of retention testing when the same drug-treatment is given both prior to acquisition and retention testing. Therefore, the compound was administered either prior to training (day 1) or prior to retention (day 2) or both prior to training and retention (day 1 and 2). In addition, a group of rats also received NDO 008 immediately after training to investigate possible effects on memory consolidation.

\section{Head-twitches}

In a separate experiment the ability of the 5-HT agonists to induce head-twitches was studied. The head-twitch response is a component of the 5-HT syndrome and is well-documented as an in vivo model of postsynaptic $5-\mathrm{HT}_{2 \mathrm{~A}}$ receptor function (Ögren et al., 1982; Peroutka \& Snyder, 1982).

The rats were placed in Macrolon ${ }^{\mathbb{R}}$ cages of the same size as their home cages. Each cage contained six rats from each treatment group. The animals were injected with $\mathrm{R}(+)-8-\mathrm{OH}-$ DPAT, NDO 008 or DOB and placed back into the same cage. The number of head-twitches were counted for a total period of $20 \mathrm{~min}(10-30 \mathrm{~min}$ post-injection) as described previously (Ögren et al., 1982).

\section{Drugs}

The following compounds were used in the present study: 3dipropylamino-5-hydroxychroman hydrochloride, NDO 008 (Astra Arcus AB, Södertälje, Sweden); two enantiomers of 8hydroxy-2-(di-n-propylamino)tetralin hydrobromide, R(+)-8OH-DPAT and $\mathrm{S}(-)-8-\mathrm{OH}-\mathrm{DPAT}$, respectively (kindly supplied by Dr Lars Erik Arvidsson, Department of Organic Pharmaceutical Chemistry, University of Uppsala, Sweden); $\mathrm{S}(+)$ - N - tert - butyl-3-(4 - (2-methoxyphenyl)piperazin-1-yl-2phenylpropionamide dihydrochloride, S(+)-WAY 100135 (Wyeth Research, Taplow, U.K.); D(+)-alprenolol hydrogen tartrate monohydrate (Hässle, Mölndal, Sweden); L( - alprenolol hydrogen tartrate monohydrate (Hässle, Mölndal, Sweden); ( \pm )-1-(4-bromo-2,5-dimethoxyphenyl)-2-aminopropane hydrochloride, DOB (synthesized by Dr Lennart Florvall, Astra Arcus AB, Södertälje, Sweden); DL( \pm )-pchlorophenylalanine, PCPA (Labkemi, Stockholm, Sweden); ketanserin tartrate (Jansen, Beerse, Belgium); pirenperone (Janssen, Beerse, Belgium); metoprolol tartrate (Hässle, Mölndal, Sweden); ICI 118551 hydrochloride (ICI, Macclesfield, U.K.).

All the drugs with the exception of pirenperone, ketanserin and PCPA were dissolved in saline $(\mathrm{NaCl} 0.9 \%)$. Pirenperone and ketanserin were dissolved in a few drops of acetic acid and distilled water and the $\mathrm{pH}$ was adjusted to 5.5. The test-drugs were administered s.c. or i.p. (as indicated in the Figure legends) in volumes of $2 \mathrm{ml} \mathrm{kg}^{-1}$ or $5 \mathrm{ml} \mathrm{kg}{ }^{-1}$, respectively. The 5-HT agonists NDO 008, R(+)- and S(-)-8-OH-DPAT and DOB were administered 10 min before PA training (if not otherwise indicated). With respect to the combination studies, the different receptor antagonists were administered at the following times before PA training: ketanserin at $20 \mathrm{~min}$, $\mathrm{S}(+)$-WAY 100135 at $30 \mathrm{~min}$ and ICI 118551, metoprolol, pirenperone, and $\mathrm{D}(+)$ - and $\mathrm{L}(-)$-alprenolol at $40 \mathrm{~min}$. All the control rats received saline $(\mathrm{NaCl} 0.9 \%)$ injections and they were run concurrently with drug-treated groups. PCPA was suspended in $1 \%$ methylcellulose and administered for three consecutive days at the doses $200 \mathrm{mg} \mathrm{kg}^{-1}$ on the first day and $100 \mathrm{mg} \mathrm{kg}^{-1}$ on the second and third days (for method description, see Ögren, 1985a). The animals were exposed to PA training one day after the last PCPA injection.
The doses of the drugs tested refer to the base or salt of the respective drug.

\section{Statistics}

The data obtained in the passive avoidance studies including the counts of rearing were analysed using Kruskal-Wallis nonparametric ANOVA. Post hoc testing with pair-wise comparisons between control groups and drug-treated groups were performed by Mann-Whitney U-test using the Bonferronicorrection for multiple comparisons. Head-twitch data were analysed by parametric one-way ANOVA followed by Dunnett's $t$-test (Kirk, 1968). A probability level of $P<0.05$ was accepted as statistically significant. Corresponding levels of probability considered for their significance in the passive avoidance and head-twitch studies are shown in the Figures.

\section{Results}

\section{Dose-related effects of $5-H T_{1 A}$ agonists on $P A$ retention}

Figure 1 shows that when tested $24 \mathrm{~h}$ after training, the retention latencies in the saline-treated control groups were very high indicating that the animals had acquired the task. In contrast, rats treated with the $\mathrm{R}(+)$ - (Figure $1 \mathrm{~A})$ and $\mathrm{S}(-)$ enantiomers (Figure 1B) of 8-OH-DPAT prior to training displayed a dose-related decrease in retention latencies (Kruskal-Wallis ANOVA: $\mathrm{H}(7)=39.0 ; P<0.001$ for $\mathrm{R}(+)-8$ OH-DPAT and $\mathrm{H}(5)=23.5 ; P<0.001$ for $\mathrm{S}(-)-8-\mathrm{OH}-\mathrm{DPAT}$, respectively). $\mathrm{R}(+)-8-\mathrm{OH}-\mathrm{DPAT}$ was about four times more active than $\mathrm{S}(-)-8-\mathrm{OH}-\mathrm{DPAT}$, producing a significant effect from the $0.06 \mathrm{mg} \mathrm{kg}^{-1}$ dose $(P<0.05$, Mann-Whitney U-test) while $\mathrm{S}(-)-8-\mathrm{OH}-\mathrm{DPAT}$ was effective from the $0.25 \mathrm{mg} \mathrm{kg}^{-1}$ dose $(P<0.02)$.

Neither $\mathrm{R}(+)$-8-OH-DPAT nor $\mathrm{S}(-)$-8-OH-DPAT affected the training latency in crossing to the dark compartment on day 1 (Table 1 ).

Similarly to the enantiomers of 8-OH-DPAT, NDO 008 induced a dose-related impairment of PA retention: $\mathrm{H}(4)=25.1 ; P<0.001$. A significant effect was found from the $0.25 \mathrm{mg} \mathrm{kg}^{-1}$ dose $(P<0.002)$ (Figure 2). No significant differences were found between control and NDO 008-treated rats with regard to the training latencies (Table 1).

Based on the dose-response experiments, the $0.13 \mathrm{mg} \mathrm{kg}^{-1}$ dose of $\mathrm{R}(+)-8-\mathrm{OH}-\mathrm{DPAT}$ and the 0.25 and $0.5 \mathrm{mg} \mathrm{kg}^{-1}$ doses of NDO 008 were chosen for all subsequent interaction studies in the PA test.

Effects of the 5-HT ${ }_{1 A}$ antagonists, $\beta$-adrenoceptor antagonists and $5-H_{2 A / 2 C}$ antagonists in counteracting impairment of $P A$ induced by $5-H T_{I A}$ agonists

Neither $\mathrm{D}(+)$-alprenolol (non-selective $\beta_{1}, \beta_{2}$ and $\beta_{3}$ receptor blocker) (4-8 $\mathrm{mg} \mathrm{kg}^{-1}$, s.c.); $\mathrm{L}(-)$-alprenolol (non-selective $\beta$-adrenoceptor $/ 5-\mathrm{HT}_{1 \mathrm{~A}}$ receptor antagonist) $\left(4-8 \mathrm{mg} \mathrm{kg}^{-1}\right.$, s.c.) nor $\mathrm{S}(+)$-WAY 100135 (selective $5-\mathrm{HT}_{1 \mathrm{~A}}$ receptor antagonist) (1-10 $\mathrm{mg} \mathrm{kg}^{-1}$, s.c.) when injected prior to training, significantly affected PA retention by themselves (data not shown).

Pretreatment with $\mathrm{S}(+)$-WAY 100135 (3 and $10 \mathrm{mg} \mathrm{kg}^{-1}$ ) completely blocked the deficit of PA caused by $\mathrm{R}(+)-8-\mathrm{OH}-$ DPAT (0.13 $\mathrm{mg} \mathrm{kg}^{-1}$, s.c.) (Figure 3A). Similarly, L(-)alprenolol $\left(4 \mathrm{mg} \mathrm{kg}^{-1}\right)$ fully antagonized the impairment of PA by both $\mathrm{R}(+)-8-\mathrm{OH}-\mathrm{DPAT}\left(0.13 \mathrm{mg} \mathrm{kg}^{-1}\right)$ and NDO 008 $\left(0.25\right.$ and $0.5 \mathrm{mg} \mathrm{kg}^{-1}$, s.c.) (Figure 3B). In contrast, the 
$\mathrm{D}(+)$-form of alprenolol failed to attenuate the disruptive effects of NDO $008\left(0.5 \mathrm{mg} \mathrm{kg}^{-1}\right)$ (Figure 3B).

Figure 4 shows that neither the $\beta_{1}$-selective antagonist metoprolol (4 $\mathrm{mg} \mathrm{kg}^{-1}$, i.p.), the $\beta_{2}$-selective antagonist ICI 118551 (4 $\mathrm{mg} \mathrm{kg}^{-1}$, i.p.) nor the $5-\mathrm{HT}_{2 \mathrm{~A} / 2 \mathrm{C}}$ nonselective antagonists ketanserin ( $1 \mathrm{mg} \mathrm{kg}^{-1}$, i.p.) and pirenperone $\left(0.1 \mathrm{mg} \mathrm{kg}^{-1}\right.$, i.p.) antagonized the impairment of PA retention by NDO $008\left(0.5 \mathrm{mg} \mathrm{kg}^{-1}\right)$ when administered prior to PA training. In addition, ketanserin $\left(1 \mathrm{mg} \mathrm{kg}^{-1}\right)$ did not attenuate the inhibitory effects of $\mathrm{R}(+)-8-\mathrm{OH}-\mathrm{DPAT}\left(0.13 \mathrm{mg} \mathrm{kg}^{-1}\right)$ (Figure 4). None of $\beta$-adrenergic or $5-\mathrm{HT}_{2 \mathrm{~A} / 2 \mathrm{C}}$ antagonists tested had any significant effect on PA retention by themselves.

Effects of PCPA-induced brain 5-HT depletion on the impairment of $P A$ retention induced by NDO 008 and $R(+)-8-O H-D P A T$

Figure 5 shows that the tryptophan hydroxylase inhibitor PCPA by itself $\left(200+100+100 \mathrm{mg} \mathrm{kg}^{-1}\right.$, i.p., for three
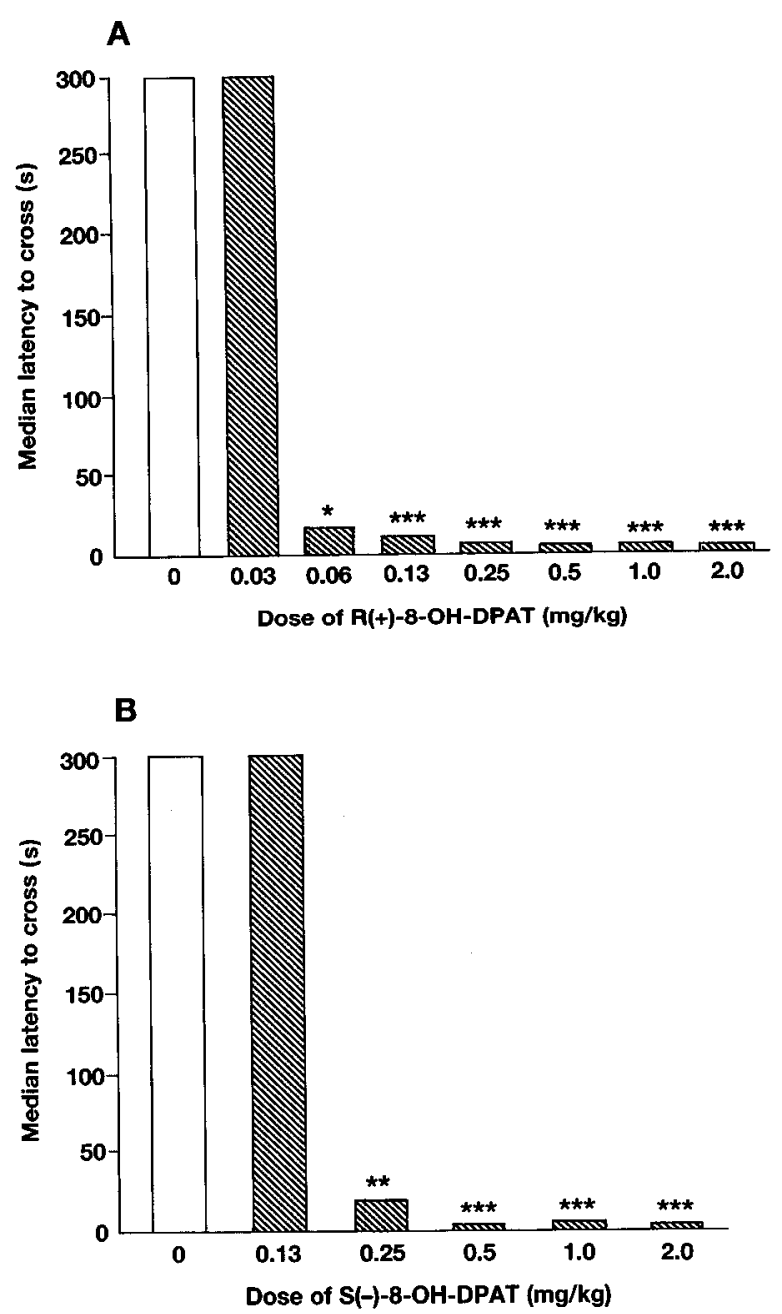

Figure 1 The dose-related effects of the two enantiomers of 8-OHDPAT on passive avoidance (PA) retention in the rat. $\mathrm{R}(+)-8-\mathrm{OH}-$ DPAT $\left(0.03-2.0 \mathrm{mg} \mathrm{kg}^{-1}\right.$, s.c.) (A) and $\mathrm{S}(-)-8-O H-D P A T ~(0.13-$ $2.0 \mathrm{mg} \mathrm{kg}^{-1}$, s.c.) (B) were administered $10 \mathrm{~min}$ before the training session (exposure to unescapable foot-shock). The retention test was performed $24 \mathrm{~h}$ later. Vertical bars represent medians of retention latencies. Maximal time of latency was set at $300 \mathrm{~s}$ (cut-off time). The statistical analysis was performed by Kruskal-Wallis ANOVA. Pairwise comparisons with a corresponding saline control group were made using Mann-Whitney U-test with the Bonferronicorrection for multiple comparisons $\left({ }^{*} P<0.05, \quad * * P<0.02\right.$, $* * * P<0.002, n=8)$. consecutive days) did not affect PA retention. The impairment of PA caused by NDO $008\left(0.5 \mathrm{mg} \mathrm{kg}^{-1}\right.$, s.c. $)$ or R(+ $)-8-\mathrm{OH}-$ DPAT $\left(0.13 \mathrm{mg} \mathrm{kg}^{-1}\right.$, s.c.) was not modified by PCPApretreatment.

\section{Role of 5- $\mathrm{HT}_{2 A}$ receptors in $\mathrm{PA}$ and head-twitch response}

Figure 6 shows that DOB $\left(0.1-2.0 \mathrm{mg} \mathrm{kg}^{-1}\right.$, s.c. $)$ injected prior to training induced an impairment of PA retention only at the highest dose tested $\left(2.0 \mathrm{mg} \mathrm{kg}^{-1}\right)(P<0.01)$ without affecting PA training latency (Table 1).

The effect of DOB on PA retention was compared with its ability to induce head-twitches. DOB $\left(0.0025-0.1 \mathrm{mg} \mathrm{kg}^{-1}\right)$ induced a dose-related increase in number of head-twitches: $\mathrm{F}(6,35)=14.7, P<0.005$. The minimum effective dose revealed in these studies was $0.01 \mathrm{mg} \mathrm{kg}^{-1}(P<0.01$, Dunnett's $t$-test), (Figure 7A), i.e. 200 fold lower than the dose which disrupted PA retention. Neither R(+)-8-OH-DPAT $\left(0.1-1.0 \mathrm{mg} \mathrm{kg}^{-1}\right)$ nor NDO $008\left(0.25-5.0 \mathrm{mg} \mathrm{kg}^{-1}\right)$ induced head-twitches at the dose range which impaired PA retention (Figure 7B).

\section{Evaluation of state-dependent learning in $P A$}

The effects of NDO $008\left(0.5 \mathrm{mg} \mathrm{kg}^{-1}\right.$, s.c. $)$ were examined in a state-dependent learning paradigm. Kruskal-Wallis ANOVA revealed significant main effect of NDO 008-treatment for the PA retention: $\mathrm{H}(4)=26.6 ; P<0.002$. The deficit of $\mathrm{PA}$ retention was seen in animals treated with NDO 008 both prior to training or prior to retention as well as prior to both training and retention (Figure 8). On the other hand, when injected immediately after training, NDO 008 did not affect retention.

\section{Behavioural observations in PA}

Both, R(+)-8-OH-DPAT $\left(0.03-2.0 \mathrm{mg} \mathrm{kg}^{-1}\right.$, s.c. $)$ and $\mathrm{S}(-)$ 8-OH-DPAT $\left(0.13-2.0 \mathrm{mg} \mathrm{kg}^{-1}\right.$, s.c.) injected $10 \mathrm{~min}$ prior to the observation period in the PA apparatus induced a dose-related development of the 5-HT syndrome. The first signs of 5-HT syndrome (lower lip retraction, flat body posture, reciprocal forepaw treading) were noted at the $0.06 \mathrm{mg} \mathrm{kg}^{-1}$ and $0.13 \mathrm{mg} \mathrm{kg}^{-1}$ doses of $\mathrm{R}(+)$ - and $\mathrm{S}(-)-8$ OH-DPAT, respectively. All the components of 5-HT syndrome (lower lip retraction, reciprocal forepaw treading, head weaving, flat body posture and hind limb abduction) but not tremor were present from the $0.13 \mathrm{mg} \mathrm{kg}^{-1}$ dose of $\mathrm{R}(+)-8-\mathrm{OH}-\mathrm{DPAT}$ and $0.25 \mathrm{mg} \mathrm{kg}^{-1}$ dose of $\mathrm{S}(-)-8-\mathrm{OH}-$ DPAT. The further increase in doses resulted in aggravation of 5-HT syndrome symptomology. A progressive decrease in cage-supported rearing up to complete abolishment and increase in forward locomotion correlated with the severity of the 5-HT syndrome and was seen at the same dose-range. The lowest $0.03 \mathrm{mg} \mathrm{kg}^{-1}$ dose of $\mathrm{R}(+)-8-\mathrm{OH}-\mathrm{DPAT}$ failed to produce visually detectable signs of the 5-HT syndrome and it did not alter rearing. A quantitative analysis of 5-HT syndrome and rearing was performed in the dose-response studies of NDO $008\left(0.1-1.0 \mathrm{mg} \mathrm{kg}^{-1}\right.$, s.c. $)$ and DOB $(0.1-$ $2.0 \mathrm{mg} \mathrm{kg}^{-1}$, s.c.) as presented in Table 2 .

The threshold-dose of NDO 008 to induce the 5-HT syndrome was $0.25 \mathrm{mg} \mathrm{kg}^{-1}$. Scores close to maximum for all the components of the 5-HT syndrome (except tremor) were found at the $0.5-1.0 \mathrm{mg} \mathrm{kg}^{-1}$ dose-range of NDO 008 . In addition, a dose-related decrease in rearing up to complete abolishment was seen in the NDO 008-treated animals from the $0.25 \mathrm{mg} \mathrm{kg}^{-1}$ dose (Table 2). 
Table 1 Dose-response effects of the selected 5-HT agonists on training latencies in passive avoidance task in the rat (day 1)

\begin{tabular}{|c|c|c|c|c|c|c|c|c|}
\hline \multirow{2}{*}{$\begin{array}{l}\text { Compound } \\
\mathrm{R}(+)-8-\mathrm{OH}-\mathrm{DPAT}\end{array}$} & \multicolumn{8}{|c|}{$\begin{array}{c}\text { Dose }(\mathrm{mg} / \mathrm{kg}) \\
\text { Training latency }(\mathrm{s}) \\
(I Q R)\end{array}$} \\
\hline & $\begin{array}{c}\mathbf{0} \\
33 \\
(15-74) \\
\mathrm{H}(7)=13.7 \text { n.s. }\end{array}$ & $\begin{array}{c}\mathbf{0 . 0 3} \\
23 \\
(17-56)\end{array}$ & $\begin{array}{c}\mathbf{0 . 0 6} \\
29 \\
(14-40)\end{array}$ & $\begin{array}{c}\mathbf{0 . 1 3} \\
11 \\
(3-25)\end{array}$ & $\begin{array}{c}\mathbf{0 . 2 5} \\
13 \\
(5-21)\end{array}$ & $\begin{array}{c}\mathbf{0 . 5} \\
17 \\
(11-21)\end{array}$ & $\begin{array}{c}\mathbf{1 . 0} \\
24 \\
(14-30)\end{array}$ & $\begin{array}{c}\mathbf{2 . 0} \\
27 \\
(23-38)\end{array}$ \\
\hline $\mathrm{S}(-)-8-\mathrm{OH}-\mathrm{DPAT}$ & $\begin{array}{c}\mathbf{0} \\
12 \\
(3-150) \\
\mathrm{H}(5)=4.2 \text { n.s. }\end{array}$ & $\begin{array}{c}\mathbf{0 . 1 3} \\
5 \\
(2-26)\end{array}$ & $\begin{array}{c}\mathbf{0 . 2 5} \\
27 \\
(10-35)\end{array}$ & $\begin{array}{c}\mathbf{0 . 5} \\
11 \\
(2-16)\end{array}$ & $\begin{array}{c}\mathbf{1 . 0} \\
15 \\
(15-32)\end{array}$ & $\begin{array}{c}\mathbf{2 . 0} \\
11 \\
(3-27)\end{array}$ & & \\
\hline NDO 008 & $\begin{array}{c}\mathbf{0} \\
17 \\
(9-37) \\
\mathrm{H}(4)=0.3 \text { n.s. }\end{array}$ & $\begin{array}{c}\mathbf{0 . 1} \\
13 \\
(9-35)\end{array}$ & $\begin{array}{c}\mathbf{0 . 2 5} \\
13 \\
(6-40)\end{array}$ & $\begin{array}{c}\mathbf{0 . 5} \\
13 \\
(8-39)\end{array}$ & $\begin{array}{c}\mathbf{1 . 0} \\
14 \\
(9-94)\end{array}$ & & & \\
\hline DOB & $\begin{array}{c}\mathbf{0} \\
33 \\
(15-74) \\
\mathrm{H}(3)=3.3 \text { n.s. }\end{array}$ & $\begin{array}{c}\mathbf{0 . 1} \\
17 \\
(14-25)\end{array}$ & $\begin{array}{c}\mathbf{1 . 0} \\
23 \\
(12-51)\end{array}$ & $\begin{array}{c}\mathbf{2 . 0} \\
17 \\
(11-30)\end{array}$ & & & & \\
\hline
\end{tabular}

The 5-HT agonists were administered subcutaneously (s.c.) 10 min prior to PA training. The values shown are median durations (corresponding interquartile ranges (IQR) shown in parentheses). Statistical analysis was performed by Kruskal-Wallis ANOVA (Hratios shown). Mann-Whitney U-test with the Bonferroni-correction $(n=6-10)$ was used to compare the different treatments of 5-HT agonists versus corresponding saline controls (0). $P$ values not shown because of their non-significance (n.s.:P>0.05). For details, see Methods.

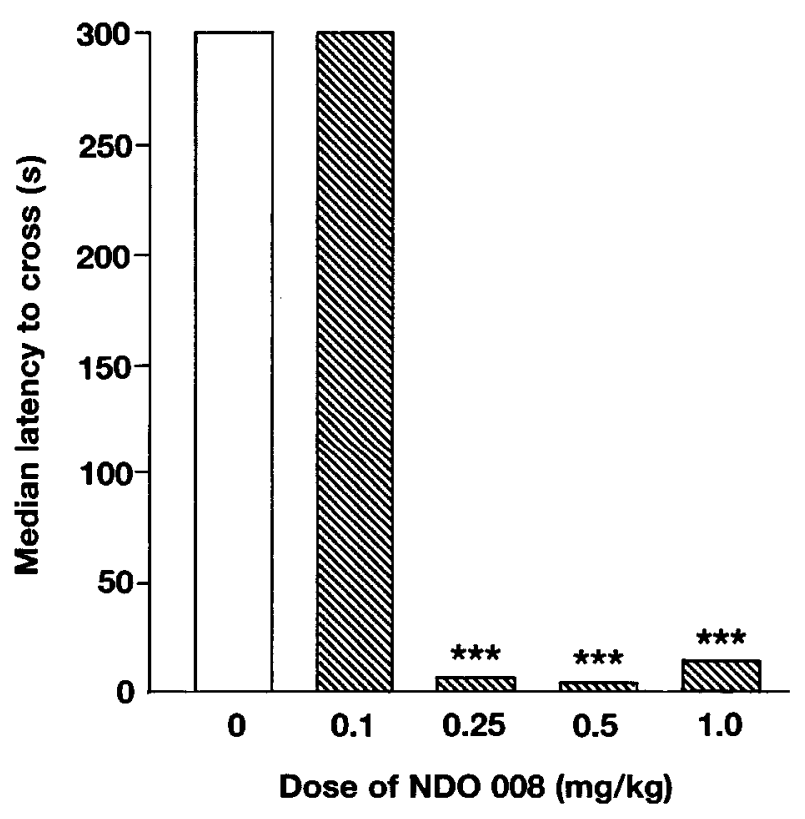

Figure 2 The dose-related effects of NDO 008 on PA retention in the rat. Rats were injected with NDO $008\left(0.1-1.0 \mathrm{mg} \mathrm{kg}^{-1}\right.$, s.c. $10 \mathrm{~min}$ before the training session. The retention test was performed $24 \mathrm{~h}$ later. Vertical bars represent medians of retention latencies $(* * * P<0.002$ versus saline control group, $n=6)$. For details of statistical analysis and general information, see legend to Figure 1.

DOB induced the 5-HT syndrome from the $1.0 \mathrm{mg} \mathrm{kg}^{-1}$ dose. Unlike NDO 008, lower lip retraction was not seen and head-weaving was occasional in DOB-treated animals. Tremor and a marked decrease of locomotor activity was noted at the highest dose of DOB $\left(2.0 \mathrm{mg} \mathrm{kg}^{-1}\right)$. In addition, respiration was heavy and forced and some of the rats chewed vacuously (1.0 and $2.0 \mathrm{mg} \mathrm{kg}^{-1}$ doses). DOB also reduced the number of rearings and a significant effect was found at the lowest $0.1 \mathrm{mg} \mathrm{kg}^{-1}$ dose $(P<0.05$, Mann-Whitney U-test) (Table 2). In addition, the animals treated with any of the $5-\mathrm{HT}_{1 \mathrm{~A}}$ agonists or DOB demonstrated an increase in arousal (startle response to sudden noise). The threshold doses were as follows: $0.13 \mathrm{mg} \mathrm{kg}^{-1}$ for $\mathrm{R}(+)-8-\mathrm{OH}$-DPAT; $0.5 \mathrm{mg} \mathrm{kg}^{-1}$ for $\mathrm{S}(-)-8-\mathrm{OH}-\mathrm{DPAT}$; $0.25 \mathrm{mg} \mathrm{kg}^{-1}$ for NDO 008 and $2.0 \mathrm{mg} \mathrm{kg}^{-1}$ DOB.

In combination studies, the 5-HT syndrome was blocked by $\mathrm{S}(+)$-WAY $100135\left(3-10 \mathrm{mg} \mathrm{kg}^{-1}\right)$ and $\mathrm{L}(-)$-alprenolol $\left(4 \mathrm{mg} \mathrm{kg}^{-1}\right)$ but not by $\mathrm{D}(+)$-alprenolol $\left(4 \mathrm{mg} \mathrm{kg}^{-1}\right)$, pirenperone $\left(0.1 \mathrm{mg} \mathrm{kg}^{-1}\right)$, ketanserin $\left(1 \mathrm{mg} \mathrm{kg}^{-1}\right)$, metoprolol $\left(4 \mathrm{mg} \mathrm{kg}^{-1}\right)$ or ICI $118551\left(4 \mathrm{mg} \mathrm{kg}^{-1}\right)$.

\section{Discussion}

In agreement with earlier reports (Carli et al., 1992; Jackson et al., 1994; Riekkinen, 1994), the selective 5-HT $1 \mathrm{~A}$-receptor agonist 8-OH-DPAT (both $\mathrm{R}(+)$ - and $\mathrm{S}(-)$-enantiomers) administered prior to training produced a dose-dependent impairment of PA retention when tested $24 \mathrm{~h}$ later. The doseresponse curves clearly indicated that $\mathrm{R}(+)-8-\mathrm{OH}-\mathrm{DPAT}$ was about four times more effective than $\mathrm{S}(-)-8-\mathrm{OH}-\mathrm{DPAT}$. However, these differences could not be directly related to changes in preference for the dark compartment since none of enantiomers affected the training latency (day 1). Another potent and selective $5-\mathrm{HT}_{1 \mathrm{~A}}$ agonist, the chroman analogue NDO 008, which is chemically related to 8-OH-DPAT (Thorberg et al., 1987), also had disruptive effects on PA retention.

Since drug-states at both training and retention tests are known to influence subsequent retention performance in aversive learning tasks (Overton, 1966), the effects of NDO 008 were examined in a state-dependent learning paradigm. NDO 008 was found to impair PA retrieval when given prior to retention. On the other hand, direct effects of NDO 008 on memory consolidation does not seem likely since post-training administration of NDO 008 did not affect PA retention when tested $24 \mathrm{~h}$ later. Interestingly, our findings are only partly in agreement with previously reported data (Carli et al., 1992; Riekkinen, 1994) showing that 8-OH-DPAT produced a marked deficit of PA retention when administered before 
training or retention but also when injected after training (post-training injections varied from $0-30 \mathrm{~min}$ ). However, according to a recent report (Carli et al., 1993), impairment of PA retention was found following pre-training but not posttraining (5 min) administration of 8-OH-DPAT into the CA1 region of the dorsal hippocampus. Taken together, the present data indicate that stimulation of $5-\mathrm{HT}_{1 \mathrm{~A}}$ receptors results in interference with acquisition processes important for avoidance learning and with the processing of information from short- to long-term memory. Activation of 5-HT $1 \mathrm{~A}$ receptors, on the other hand, appears not to interfere with the post-trial consolidation processes. However, 5- $\mathrm{HT}_{1 \mathrm{~A}}$ receptors appear to be involved in memory retrieval of an aversive experience.

A major problem in studying the role of 5-HT in aversive learning and memory is that changes in 5-HT neurotransmission can alter sensorimotor reactivity (Davis et al., 1980). It is well-documented that $5-\mathrm{HT}_{1 \mathrm{~A}}$ agonists induce multiple behavioural effects, e.g. modulate both general locomotor
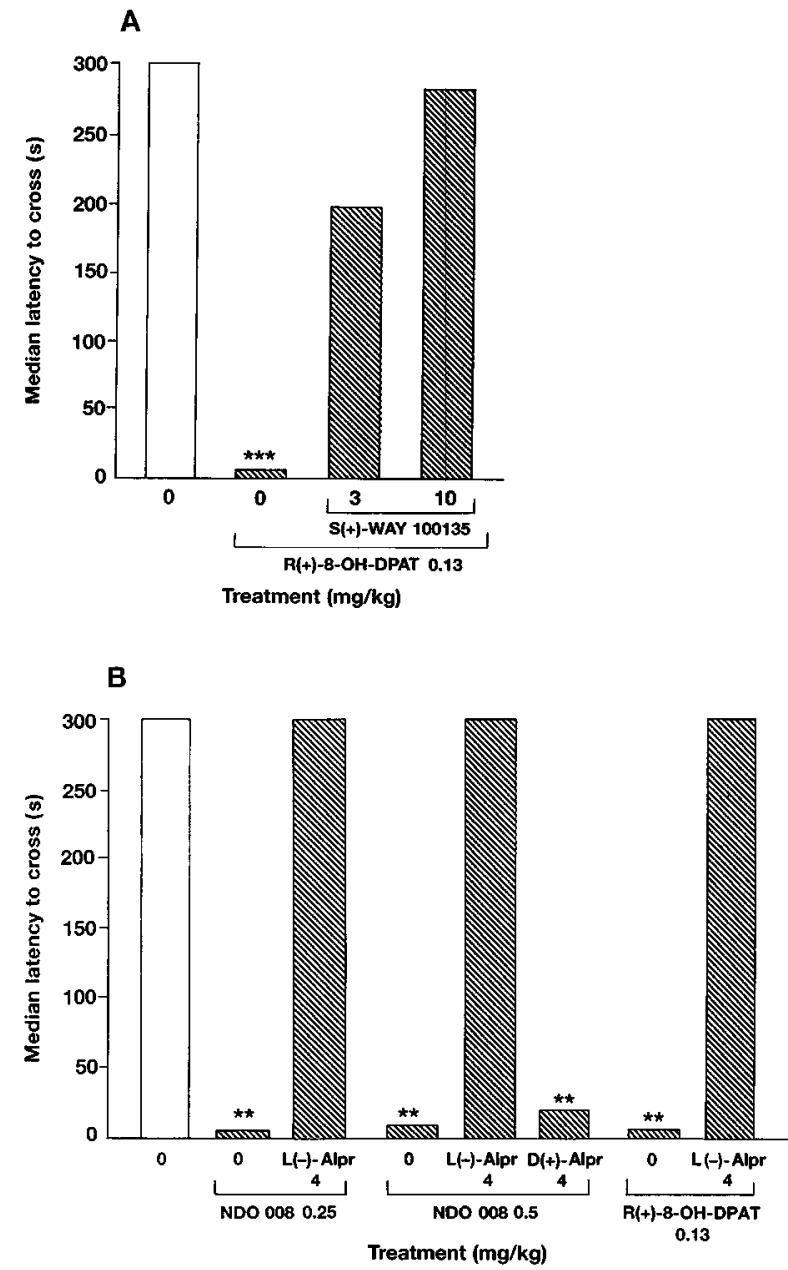

Figure 3 The effects of S(+)-WAY 100135 (A) and L(-)- and $\mathrm{D}(+)$-alprenolol (B) on the impairment of PA retention caused by NDO 008 or $\mathrm{R}(+)-8-\mathrm{OH}-\mathrm{DPAT}$ in the rat. Rats were injected with either $\mathrm{S}(+)$-WAY 100135 (3 and $10 \mathrm{mg} \mathrm{kg}^{-1}$, s.c.) or $\mathrm{L}(-)$ - and $\mathrm{D}(+)$-enantiomers of alprenolol $\left(4 \mathrm{mg} \mathrm{kg}^{-1}\right.$, s.c.) 30 or $40 \mathrm{~min}$ before the training session, respectively. Subsequently, NDO 008 $\left(0.25\right.$ and $0.5 \mathrm{mg} \mathrm{kg}^{-1}$, s.c.) or $\mathrm{R}(+)-8$-OH-DPAT $\left(0.13 \mathrm{mg} \mathrm{kg}^{-1}\right.$, s.c.) was administered $10 \mathrm{~min}$ before the training session. Retention test was performed $24 \mathrm{~h}$ later. Vertical bars represent medians of retention latencies $(* * * P<0.002$ versus saline control group, $n=8$ (A) and ${ }^{* *} P<0.02$ versus saline control group, $n=8-10(\mathrm{~B})$ ). For details of statistical analysis and general information, see legend to Figure 1. L(-)-Alpr, L(-)-alprenolol; D(+)-Alpr, D(+)-alprenolol.

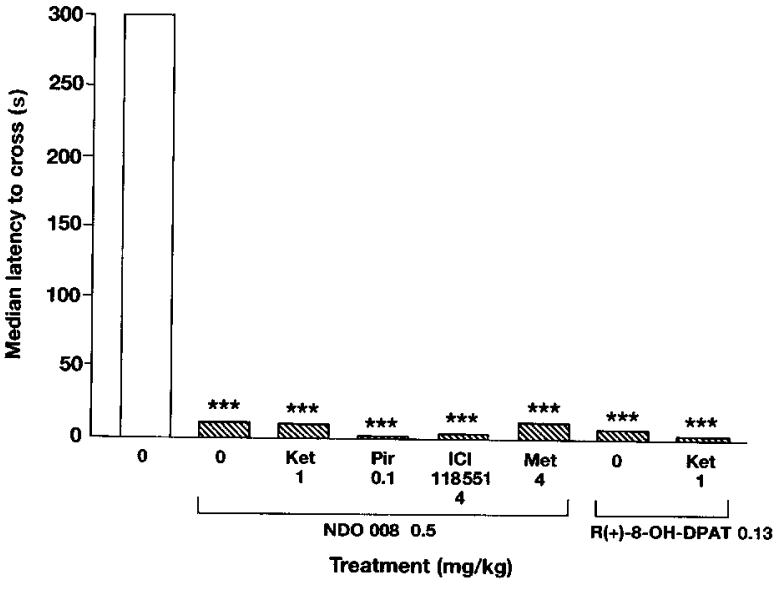

Figure 4 The effects of the $5-\mathrm{HT}_{2 \mathrm{~A} / 2 \mathrm{C}}$ receptor antagonists ketanserin and pirenperone and the $\beta$-adrenoceptor antagonists ICI 118551 and metoprolol on the impairment of PA retention induced by NDO 008 and $\mathrm{R}(+)-8-\mathrm{OH}-\mathrm{DPAT}$ in the rat. The different receptor antagonists were injected at the following times prior to PA training: ketanserin ( $1 \mathrm{mg} \mathrm{kg}^{-1}$, i.p.) $20 \mathrm{~min}$, pirenperone (0.1 $\mathrm{mg} \mathrm{kg}^{-1}$, i.p.) $40 \mathrm{~min}$, ICI 118551 ( $4 \mathrm{mg} \mathrm{kg}^{-1}$, i.p.) $40 \mathrm{~min}$ and metoprolol (4 $\mathrm{mg} \mathrm{kg}^{-1}$, i.p.) $40 \mathrm{~min}$. The $5-\mathrm{HT}_{1 \mathrm{~A}}$ agonists NDO $008\left(0.5 \mathrm{mg} \mathrm{kg}^{-1}\right.$, s.c.) and $\mathrm{R}(+)-8-\mathrm{OH}-\mathrm{DPAT}\left(0.13 \mathrm{mg} \mathrm{kg}^{-1}\right.$, s.c. $)$ were administered $10 \mathrm{~min}$ prior to PA training. Retention test was performed $24 \mathrm{~h}$ after the training session. Vertical bars represent medians of retention latencies $(* * * P<0.002$ versus saline control group, $n=6-8$ ). For details of statistical analysis and general information, see legend to Figure 1. Ket, ketanserin; Pir, pirenperone; Met, metoprolol.

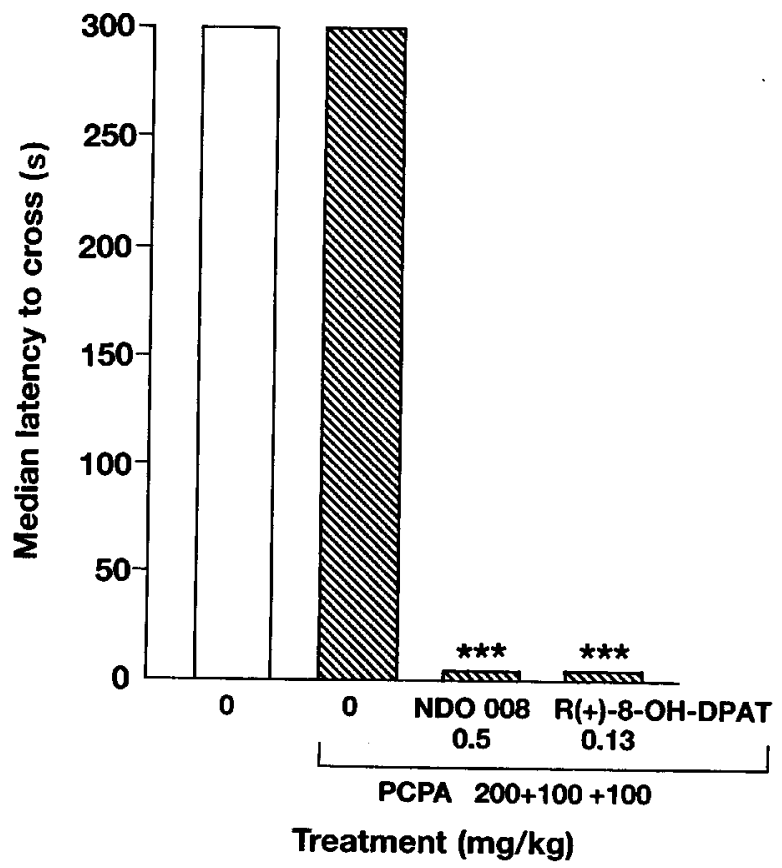

Figure 5 The effects of $\mathrm{R}(+)-8-\mathrm{OH}-\mathrm{DPAT}$ and NDO 008 on PA retention after pretreatment with p-chlorophenylalanine (PCPA; $200+100+100 \mathrm{mg} \mathrm{kg}^{-1}$, i.p., for three consecutive days) in the rat. The PA training session was performed $24 \mathrm{~h}$ after the last PCPA injection. $\mathrm{R}(+)-8-\mathrm{OH}-\mathrm{DPAT}\left(0.13 \mathrm{mg} \mathrm{kg}^{-1}\right.$, s.c. $)$ and NDO 008 $\left(0.5 \mathrm{mg} \mathrm{kg}^{-1}\right.$, s.c.) were administered $10 \mathrm{~min}$ before the training session. Retention test was performed $24 \mathrm{~h}$ later. Vertical bars represent medians of retention latencies $(* * * P<0.002$ versus PCPAtreated group, $n=6$ ). For details of statistical analysis and general information, see legend to Figure 1. 
activity (Dourish et al., 1985; Curzon, 1990; Evenden \& Angeby-Moller, 1990), nociceptive thresholds (Hamon et al., 1990) and elicit a characteristic behavioural syndrome (5-HT syndrome) (Tricklebank et al., 1984; Berendsen et al., 1989; Blanchard et al., 1993). Therefore, it is quite possible that these factors may interfere with learning performance (Ögren, $1985 b$ ) by alteration of sensory input at the initial stage of information processing. Changes in nociceptive thresholds, e.g. flinch and jump threshold elicited by electric shock, have been reported to be reduced at the doses of 8-OH-DPAT producing impairment of PA (Carli et al., 1992). However, alterations in shock-sensitivity (or rather its expression, i.e. reactivity to shock) are not likely to explain the present results. Thus, it was observed that the animals reacted to the shock, mostly by a flinch response or by moving, sometimes vocalizing. It should be emphasized that the shock used in the present study was scrambled and its level was well above the threshold for a flinch response (withdrawal of forepaws from the grid floor). Moreover, the increased startle-response was observed at the high doses of $\mathrm{R}(+)$ - and S(-)-8-OH-DPAT and NDO 008 which induced both a loss of PA retention and a progressive development of the 5-HT syndrome. These observations suggest that the actual perception of shock might be increased rather than suppressed by $5-\mathrm{HT}_{1 \mathrm{~A}}$ agonists.

The present data have provided strong evidence for the view that both 8-OH DPAT and NDO 008 produced their effects on $\mathrm{PA}$ via stimulation of 5- $\mathrm{HT}_{1 \mathrm{~A}}$ receptors. Both the non-selective $\beta$-adrenoceptor $/ 5-\mathrm{HT}_{1 \mathrm{~A}}$ antagonist $\mathrm{L}(-)$-alprenolol (Nahorski \& Willcocks, 1983; Middlemiss et al., 1985, 1986) and the selective $5-\mathrm{HT}_{1 \mathrm{~A}}$ receptor antagonist $\mathrm{S}(+)$-WAY 100135 (Fletcher et al., 1993) completely blocked the impairment of

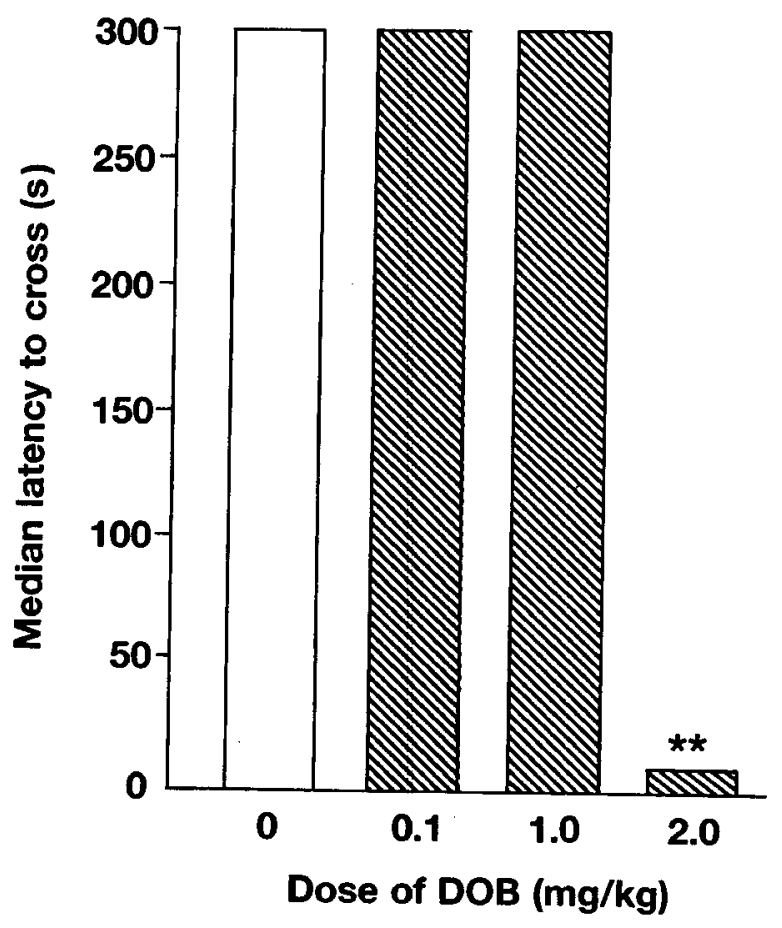

Figure 6 The dose-related effects of DOB on PA retention in the rat. Rats were injected with DOB $\left(0.1-2.0 \mathrm{mg} \mathrm{kg}^{-1}\right.$, s.c.) $10 \mathrm{~min}$ before the training session. The retention test was performed $24 \mathrm{~h}$ later. Vertical bars represent medians of retention latencies $(* * P<0.01$ versus saline control group, $n=8)$. For details of statistical analysis and general information, see legend to Figure 1.
PA retention and the 5-HT behavioural syndrome as well as the decrease in the rearing induced by NDO 008 and R(+)-8$\mathrm{OH}-\mathrm{DPAT}$. Interestingly, the blockade of $5-\mathrm{HT}_{1 \mathrm{~A}}$ receptors by $\mathrm{L}(-)$-alprenolol and $\mathrm{S}(+)$-WAY 100135 itself failed to produce any significant changes in retention suggesting that the $5-\mathrm{HT}_{1 \mathrm{~A}}$ receptors play a permissive role in this behavioural task. Consistent with the above interpretation, the $5-\mathrm{HT}_{2 \mathrm{~A} / 2 \mathrm{C}}$ antagonists, ketanserin and pirenperone (Leysen et al., 1982; 1984; Pawlowski et al., 1983; Hoyer et al., 1994), both given at doses which blocked brain $5-\mathrm{HT}_{2 \mathrm{~A} / 2 \mathrm{C}}$ receptor actions in vivo (Ögren, 1986b), failed to reverse the actions of NDO 008 and 8-OH-DPAT. Therefore, $5-\mathrm{HT}_{1 \mathrm{~A}}$ receptors rather than $5-\mathrm{HT}_{2 \mathrm{~A}}$ receptors seem to be involved in the modulation of $\mathrm{PA}$. This conclusion was further corroborated by the results obtained with DOB, a non-selective $5-\mathrm{HT}_{2 \mathrm{~A} / 2 \mathrm{C}}$ receptor agonist (Glennon et al., 1984; Titeler et al., 1985; Titeler \& Lyon, 1987). DOB was found to be very effective in inducing headtwitches, a response attributed to postsynaptic 5-HT $2 \mathrm{~A}$ receptor stimulation (Ögren et al., 1982; Peroutka \& Snyder, 1982) from the $0.01 \mathrm{mg} \mathrm{kg}^{-1}$ dose while a 200 fold higher dose was needed to induce impairment of PA retention. However, this impairment might be due to the observed toxic effects of DOB or the hallucinogenic properties of the compound (Martin \& Sloan, 1986; Glennon et al., 1992). The possible role of the $5-\mathrm{HT}_{2 \mathrm{C}}$ receptors in the inhibitory action of $\mathrm{DOB}$ awaits further studies.

8-OH-DPAT is a relatively selective $5-\mathrm{HT}_{1 \mathrm{~A}}$ agonist with at least ten times higher affinity for the $5-\mathrm{HT}_{1 \mathrm{~A}}$ receptor than for any other receptor type according to the available radioligandbinding data (Hoyer et al., 1994). Recent results show that 8-OH-DPAT also possesses a relatively high affinity for the
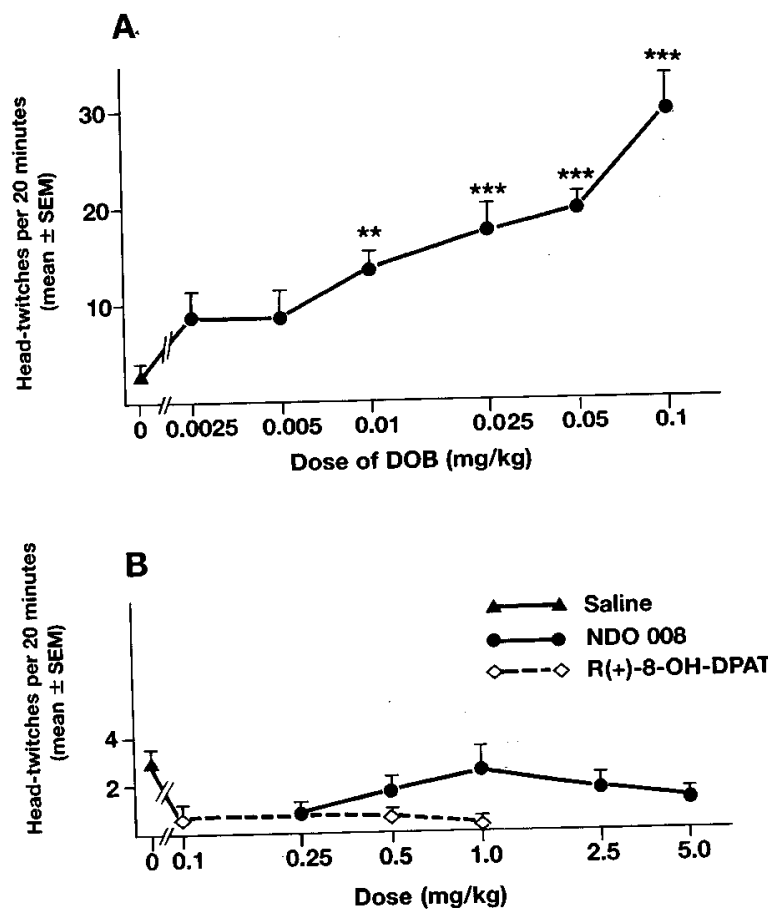

Figure 7 The effectiveness of different 5-HT agonists to induce headtwitches in the rat. Rats were injected with selected doses of either DOB (0.0025-0.1 mg kg${ }^{-1}$, s.c.) (A) or R(+)-8-OH-DPAT $\left(0.1-1.0 \mathrm{mg} \mathrm{kg}^{-1}\right.$, s.c.) and NDO $008\left(0.25-5.0 \mathrm{mg} \mathrm{kg}^{-1}\right.$, s.c.) (B). The corresponding controls were injected with saline $\left(2 \mathrm{ml} \mathrm{kg}{ }^{-1}\right.$, s.c. $)$. The number of head-twitches was counted for $20 \mathrm{~min}(10-30 \mathrm{~min}$ following injection). The results are expressed as means \pm s.e.m. (only positive errors shown) for each of the doses tested. Statistical analysis was performed by one-way ANOVA followed by Dunnett's $t$-test (one-tailed). $* * P<0.01$ versus saline control group and $* * * P<0.005$ versus saline control group, $n=6$. 
cloned rat and human $5-\mathrm{HT}_{7}$ receptors (Ruat et al., 1993; Boess \& Martin, 1994; Eglen et al., 1997). Therefore, an involvement of this receptor subtype in the actions of 8-OHDPAT could be hypothesized but seems unlikely. Firstly, S(+)-WAY 100135, which completely antagonized the 8-OHDPAT-induced impairment in the PA task, has a negligible affinity for the 5- $\mathrm{HT}_{7}$ receptor (Hoyer et al., 1994; Routledge, 1996). Secondly, the present findings indicate that the non-

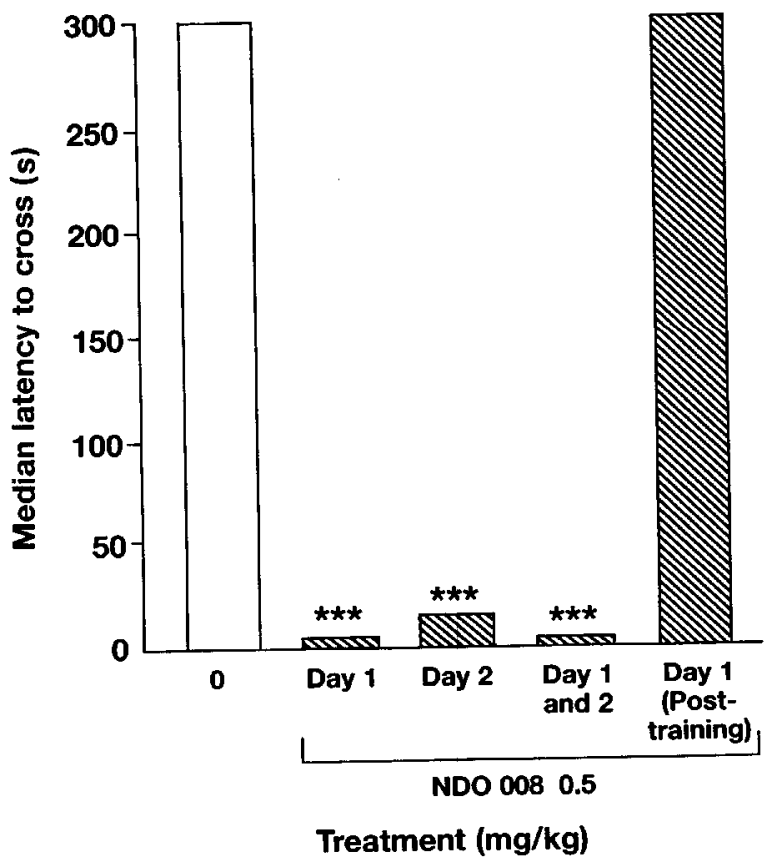

Figure 8 The effects of NDO 008 on PA retention using a statedependent learning paradigm in the rat. Rats were injected with NDO $008\left(0.5 \mathrm{mg} \mathrm{kg}^{-1}\right.$, s.c.) either $10 \mathrm{~min}$ prior to training (day 1), 10 min prior to retention (day 2), or 10 min prior to both training and retention (days 1 and 2). In addition, a group injected with NDO 008 immediately after the training session on day 1 was tested. Retention test was performed $24 \mathrm{~h}$ after the training session. Vertical bars represent medians of retention latencies $(* * * P<0.002$ versus saline control group, $n=6-8$ ). For details of statistical analysis and general information, see legend to Figure 1. selective $5-\mathrm{HT}_{2 \mathrm{~A} / 2 \mathrm{C}}$ antagonist ketanserin with a slightly lower affinity for the 5- $\mathrm{HT}_{7}$ receptor than 8-OH-DPAT (Hoyer et al., 1994) did not counteract the inhibitory effect of $\mathrm{R}(+)-8-\mathrm{OH}-$ DPAT in the PA test.

Many $5-\mathrm{HT}_{1 \mathrm{~A}}$ ligands currently used as pharmacological tools also have notable affinities for $\beta$-adrenoceptors (Hjorth \& Carlsson, 1986; Sanchez et al., 1996). However, in these studies none of the antagonists with a preferential binding to $\beta$ adrenoceptors, i.e. the $\beta_{1}$-selective antagonist metoprolol or the $\beta_{2}$-selective antagonist ICI 118551 (Nahorski \& Willcocks, 1983; Bylund et al., 1994; Hieble et al., 1995; Ruffolo et al., $1995)$ or $\mathrm{D}(+)$-alprenolol ( $\beta$-adrenoceptor blocker nearly equipotent at $\left(\beta_{1}, \beta_{2}\right.$, and $\beta_{3}$ sites) (Middlemiss, 1986) antagonized the effects of either $\mathrm{R}(+)-8-\mathrm{OH}-\mathrm{DPAT}$ or NDO 008. The importance of the relative selectivity for $5-\mathrm{HT}_{1 \mathrm{~A}}$ receptors over $\beta$-adrenoceptors was illustrated by $\mathrm{L}(-)$ alprenolol.

The role of presynaptic versus postsynaptic $5-\mathrm{HT}_{1 \mathrm{~A}}$ receptors in the disruptive actions of NDO 008 and $8-\mathrm{OH}-$ DPAT in PA are of particular importance for the analysis of mechanisms underlying aversive conditioning. Some investigators have suggested that the effects of $5-\mathrm{HT}_{1 \mathrm{~A}}$ agonists on aversive learning processes such as licking suppression or conditioned emotional responses (CER) (Schreiber \& de Vry, 1993 ) or the anticonflict action of 8-OH-DPAT (Engel et al., 1984) are related to stimulation of presynaptic $5-\mathrm{HT}_{1 \mathrm{~A}}$ receptors. The present data, on the other hand, support the view that the impaired PA retention caused by the $5-\mathrm{HT}_{1 \mathrm{~A}}$ receptor agonists is mainly due to stimulation of postsynaptic 5- $\mathrm{HT}_{1 \mathrm{~A}}$ receptors. Firstly, both NDO 008 and 8-OH-DPAT induced the 5-HT syndrome indicative of a stimulation of postsynaptic 5- $\mathrm{HT}_{1 \mathrm{~A}}$ receptors (Goodwin et al., 1987; Curzon, 1990) at the dose range at which they inhibited PA. Furthermore, S(+)-WAY 100135 completely antagonized both the impairment of PA retention and the 5-HT syndrome induced by $\mathrm{R}(+)-8-\mathrm{OH}-\mathrm{DPAT}$. Secondly, inhibition of 5-HT synthesis by PCPA did not have any significant effect on PA. PCPA markedly reduces the pool of available 5-HT in the presynaptic neurones (Koe \& Weissman, 1966). Thus, the treatment paradigm with PCPA used in the present study has been reported to result in about $80-90 \% 5$-HT depletion in the rat brain (Ögren, 1985b). In the present study pretreatment

Table 2 The behavioural responses (5-HT syndrome and rearing) to NDO 008 and DOB in the passive avoidance (PA) apparatus in the rat

\begin{tabular}{|c|c|c|c|c|c|c|c|}
\hline \multirow[b]{2}{*}{$\begin{array}{l}\text { Compound } \\
(\text { Dose, } m g / k g)\end{array}$} & \multicolumn{6}{|c|}{ Intensity scores of 5-HT syndrome } & \multirow[b]{2}{*}{ Rearing } \\
\hline & $\begin{array}{l}\text { Lower lip } \\
\text { retraction }\end{array}$ & $\begin{array}{l}\text { Reciprocal fore- } \\
\text { paw treading }\end{array}$ & $\begin{array}{c}\text { Head } \\
\text { weaving }\end{array}$ & $\begin{array}{l}\text { Flat body } \\
\text { posture }\end{array}$ & $\begin{array}{l}\text { Hind limb } \\
\text { abduction }\end{array}$ & Tremor & \\
\hline \multicolumn{8}{|l|}{ NDO 008} \\
\hline 0 & 0 & 0 & 0 & 0 & 0 & 0 & $11.5(10-16)$ \\
\hline 0.1 & 0 & 0 & 0 & 0 & 0 & 0 & $12.0 \quad(9-19)$ \\
\hline 0.25 & 1 & 2 & 0 & 0 & 2 & 0 & $0.5(0-4)^{* * *}$ \\
\hline 0.5 & 3 & 3 & 2 & 3 & 2 & 0 & $0.0(0-1)^{* *}$ \\
\hline 1.0 & 3 & 3 & 3 & 3 & 2 & 0 & $0.5(0-3)^{* *}$ \\
\hline \multicolumn{8}{|l|}{$D O B$} \\
\hline 0 & 0 & 0 & 0 & 0 & 0 & 0 & $9.0 \quad(7-18)$ \\
\hline 0.1 & 0 & 1 & 1 & 1 & 2 & 0 & $7.0 \quad(3-11)^{*}$ \\
\hline 1.0 & 0 & 3 & 1 & 3 & 3 & 0 & $2.0 \quad(0-5)^{* * *}$ \\
\hline 2.0 & 0 & 2 & 0 & 3 & 2 & 1 & $1.0(0-3)^{* * *}$ \\
\hline
\end{tabular}

The 5-HT syndrome was scored and number of rearings was counted in the PA apparatus during a 3 min exploration period prior to training (day 1). The 5-HT agonists were administered subcutaneously (s.c.) 10 min prior to observations ( $n=6-9$ animals/group). Intensity scores of 5-HT syndrome were as follows: $0=$ absent, $1=$ equivocal, $2=$ present and $3=$ intense. The presented values for the 5 -HT syndrome and rearing are medians (for rearing corresponding interquartile ranges (IQR) shown in parentheses). Statistical analysis for rearing was performed by Kruskal-Wallis ANOVA: $\mathrm{H}(4)=22.1, P<0.002$ and $\mathrm{H}(3)=24.7, P<0.002$ for $\mathrm{NDO} 008-$ and DOB-treatments, respectively. Mann-Whitney U-test with the Bonferroni-correction for multiple comparisons was used to compare the treatments of 5 -HT agonists versus corresponding saline controls $(0)$ : $* P<0.05 ; * * P<0.02$; $* * *<0.002$. For details, see Methods. 
with PCPA attenuated neither the 5-HT syndrome nor the deficit of PA induced by NDO 008 or R(+)-8-OH-DPAT. Therefore, reduced impulse flow and/or diminished 5-HT availability resulting from any presynaptic action of NDO 008 or 8-OH-DPAT on serotonergic neurones appears not to be sufficient to alter $\mathrm{PA}$ retention.

However, the contribution of the presynaptic 5-HT receptor mechanisms (5- $\mathrm{HT}_{1 \mathrm{~A}}$-related or non-related) in the regulation of PA behaviour requires further analysis. It cannot be excluded that the inhibitory action of 8-OH-DPAT on PA also involves the recently discovered $5-\mathrm{HT}_{1 \mathrm{~A}}$ binding sites (5- $\mathrm{HT}_{1 \mathrm{~A}}{ }^{\text {LOW }}$ sites), apparently localized on the presynaptic 5-HT terminals both in the hippocampus and cortex (Nenonene et al., 1994). These 5- $\mathrm{HT}_{1 \mathrm{~A}}$ binding sites which are recognized by 8 -OH-DPAT must be distinguished from classical postsynaptic $5-\mathrm{HT}_{1 \mathrm{~A}}$ receptors $\left(5-\mathrm{HT}_{1 \mathrm{~A}}{ }^{\mathrm{HIGH}}\right.$ sites). Thus, these novel 5- $\mathrm{HT}_{1 \mathrm{~A}}{ }^{\mathrm{LOW}}$ sites are not affected by PCPA, but 'disappear' following PCA-induced destruction of 5-HT terminals (Nenonene et al., 1994). These particular binding sites must also be distinguished from 5-HT terminal autoreceptors of the 5- $\mathrm{HT}_{1 \mathrm{~B}}$ type (Martin \& Sanders-Bush, 1982; Hartig et al., 1996) which are little affected by 8-OHDPAT or NDO 008 (Hoyer et al., 1985, 1994; Engel et al., 1986).

Consistent with previous data on 5-HT receptor activity in vivo (Arvidsson et al., 1981; 1984; Björk et al., 1989; Cornfield et al., 1991; Hadrava et al., 1996), the two enantiomers of 8-OH-DPAT differed, since $\mathrm{R}(+)-8-\mathrm{OH}$-DPAT was about four times more effective than $\mathrm{S}(-)-8-\mathrm{OH}-\mathrm{DPAT}$ to impair PA retention. This difference in effectiveness is in agreement with electrophysiological studies showing that the $\mathrm{R}(+)$ enantiomer is $2-3$ times more potent than $\mathrm{S}(-)-8-\mathrm{OH}-\mathrm{DPAT}$ in suppressing the neuronal firing both at the level of the dorsal raphe (Lejeune et al., 1997) and in the dorsal hippocampus (CA3 area) (Hadrava et al., 1996), thus indicating a greater agonistic activity of $\mathrm{R}(+)-8-\mathrm{OH}-\mathrm{DPAT}$. Since receptor binding studies have revealed no significant differences of the two enantiomers in terms of their affinity for the 5-HT $1 \mathrm{~A}$ receptor (Lejeune et al., 1997), a role of stereoselectivity in their intrinsic activity and coupling to G-proteins must be considered (Björk et al., 1989; Cornfield et al., 1991).

Interestingly, the $\mathrm{R}(+)$-and $\mathrm{S}(-)$ - enantiomers of $8-\mathrm{OH}$ DPAT have been shown to behave as full and partial agonists, respectively, in inhibiting forskolin-stimulated cAMP production at postsynaptic $5-\mathrm{HT}_{1 \mathrm{~A}}$ receptors in the hippocampus (Cornfield et al., 1991; Foreman et al., 1995). However, recently both enantiomers of 8-OH-DPAT have been reported to act as partial agonists in antagonizing the effect of 5-HT at the postsynaptic hippocampal CA3 neurones (Hadrava et al., 1996). Therefore, it is possible that the different biological activities of the $\mathrm{R}(+)$ - and $\mathrm{S}(-)$-isomers of 8-OH-DPAT reflect variations in the $5-\mathrm{HT}_{1 \mathrm{~A}}$ receptor coupling to multiple G-proteins.

Taken together, the present data indicate that the deficit of $\mathrm{PA}$ retention induced by the $5-\mathrm{HT}_{1 \mathrm{~A}}$ agonists is due to stimulation of the postsynaptic $5-\mathrm{HT}_{1 \mathrm{~A}}$ receptors. The $5-\mathrm{HT}_{1 \mathrm{~A}}$ receptor stimulation appears to interfere with learning processes operating at both acquisition and retrieval.

We thank Dr Veveca Nerme and Dr Bengt Åblad (Hässle, Mölndal, Sweden) for generous supplies of the $\mathrm{L}(-)$ - and $\mathrm{D}(+)$-isomers of alprenolol and Dr Lars Erik Arvidsson for the supply of the R(+)and $\mathrm{S}(-)$-enantiomers of 8-OH-DPAT. This work was supported in parts by grant of the Swedish Medical Research Council (MFR; project No K97-14X-11588-02B) and Kapten Artur Erikssons Stiftelse (1997). Ilga Misane was supported in parts by grants of the Swedish Institute, KIRT (Karolinska Institute) and the Royal Swedish Academy of Sciences.

\section{References}

ARVIDSSON, L.E., HACKSELL, U., JOHANSSON, A.M., NILSSON, J.L.G., LINDBERG, P., SANCHEZ, D., WIKSTRÖM, H., SVENSSON, K., HJORTH, S. \& CARLSSON, A. (1984). 8-Hydroxy-2-(alkylamino)tetralins and related compounds as central 5-hydroxytryptamine receptor agonists. J. Med. Chem., 27, 45-51.

ARVIDSSON, L.E., HACKSELL, U., NILSSON, J.L.G., HJORTH, S., CARLSSON, A., LINDBERG, P., SANCHEZ, D. \& WIKSTRÖM, H. (1981). 8-Hydroxy-2-(di-n-propylamino) tetralin, a new centrally acting 5-hydroxytryptamine receptor agonist. J. Med. Chem., 24, $921-923$

BERENDSEN, H.H.G., JENCK, F. \& BROEKKAMP, C.L.E. (1989) Selective activation of $5-\mathrm{HT}_{1 \mathrm{~A}}$ receptors induces lower lip retraction in the rat. Pharmacol. Biochem. Behav., 33, 821-827.

BJÖRK, L., HOOK, B.B., NELSON, D.L., ANDEN, N.E. \& HACKSELL, U. (1989). Resolved N,N-dialkylated 2-amino-8-hydroxytetralins: stereoselective interactions with $5-\mathrm{HT}_{1 \mathrm{~A}}$ receptors in the brain. J. Med. Chem., 32, $779-783$.

BLANCHARD, R.J., SHEPHERD, J.K., ARMSTRONG, J., TSUDA, S.F. \& BLANCHARD, D.C. (1993). An ethopharmacological analysis of the behavioural effects of 8-OH-DPAT. Psychopharmacology, 112, $55-65$.

BOESS, F.G. \& MARTIN, I.L. (1994). Molecular biology of 5-HT receptors. Neuropharmacology, 33, 275-317.

BYLUND, D.B., EIKENBERG, D.C., HIEBLE, J.P., LANGER, S.Z., LEFKOWITZ, R.J., MINNEMAN, K.P., MOLINOFF, P.B., RUFFOLO, R.R.J. \& TRENDELENBURG, U. (1994). International Union of Pharmacology nomenclature of adrenoceptors. Pharmacol. Rev., 46, $121-136$

CARLI, M., TATARCZYNSKA, E., CERVO, L. \& SAMANIN, R. (1993). Stimulation of hippocampal $5-\mathrm{HT}_{1 \mathrm{~A}}$ receptors causes amnesia and anxiolytic-like but not antidepressant-like effects in the rat. Eur. J. Pharmacol., 234, 215-221.

CARLI, M., TRANCHINA, S. \& SAMANIN, R. (1992). 8-Hydroxy-2(di-n-propylamino)tetralin, a $5-\mathrm{HT}_{1 \mathrm{~A}}$ receptor agonist, impairs performance in a passive avoidance task. Eur. J. Pharmacol., 211, $227-234$.

CORNFIELD, L.J., LAMBERT, G., ARVIDSSON, L.E., MELLIN, C., VALLGARDA, J., HACKSELL, U. \& NELSON, D.L. (1991). Intrinsic activity of enantiomers of 8-hydroxy-2-(di-n-propylamino)tetralin and its analogs at 5-hydroxytryptamine ${ }_{1 \mathrm{~A}}$ receptors that are negatively coupled to adenylate cyclase. Mol. Pharmacol., 39, $780-787$

COSSERY, J.M., GOZLAN, H., SHAMPINATO, U., PERDICAKIS, C., GUillaumet, G., PICHAT, L. \& HAMON, M. (1987). The selective labelling of central $5-\mathrm{HT}_{1 \mathrm{~A}}$ receptor binding sites by $\left[{ }^{3} \mathrm{H}\right] 5$-methoxy-3-(di-n-propylamino)chroman. Eur. J. Pharmacol., 140, $143-155$.

CURZON, G. (1990). Stereotyped and other motor responses to 5hydroxytryptamine receptor activation. In Neurobiology of stereotyped behaviour, ed. Cooper, S.J. \& Dourish, C.T. pp. 142 - 167. Oxford: University Press.

DAVIS, M., ASTRACHAN, D.I. \& KASS, E. (1980). Excitatory and inhibitory effects of serotonin on sensorimotor reactivity measured with acoustic startle. Science, 209, 521-523.

DOURISH, C.T., HUTSON, P.J. \& CURZON, G. (1985). Low doses of the putative serotonin agonist 8-hydroxy-2-(di-n-propylamino)tetralin (8-OH-DPAT) elicit feeding in the rat. Psychopharmacology, 86, $197-204$.

EGLEN, R.M., JASPER, J.R., CHANG, D.J. \& MARTIN, J.R. (1997). The 5- $\mathrm{HT}_{7}$ receptor: orphan found. TIPS, 18, 104-107. 
ENGEL, G., GÖTHERT, M., HOYER, D., SCHLICKER, E. \& HILLENBRAND, K. (1986). Identity of inhibitory presynaptic 5-hydroxytryptamine (5-HT) autoreceptors in the rat brain cortex with 5$\mathrm{HT}_{1 \mathrm{~B}}$ binding sites. Naunyn-Schmiedeberg's Arch. Pharmacol., 332, $1-7$.

ENGEL, J.A., HJORTH, S., SVENSSON, K., CARLSSON, A. \& LILJEQUIST, S. (1984). Anticonflict effect of the putative serotonin receptor agonist 8-hydroxy-2-(di-n-propylamino)tetralin (8-OH-DPAT). Eur. J. Pharmacol., 105, 365-368.

EVENDEN, J.L. \& ANGEBY-MOLLER, K. (1990). Effects of 8hydroxy-2-(di-n-propylamino)tetralin (8-OH-DPAT) on locomotor activity and rearing of mice and rats. Psychopharmacology, 102, 485-491.

FLETCHER, A., BILL, D.J., BILL, S.J., CLIFFE, I.A., DOVER, G.M., FORSTER, E.A., HASKINS, J.T., JONES, D., MANSELL, H.L. \& REILLY, Y. (1993). WAY 100135: a novel, selective antagonist at presynaptic and postsynaptic 5- $\mathrm{HT}_{1 \mathrm{~A}}$ receptors. Eur. J. Pharmacol., 237, 283-291.

FOREMAN, M.M., FULLER, R.W., LEANDER, J.D., NELSON, D.L., CALligARO, D.O., LUCAITES, V.L., WONG, D.T., ZHANG, L., BARRET, J.E. \& SCHAUS, J.M. (1995). Pharmacological characterisation of enantiomers of 8-thiometyl-2-(di-n-propylamino)tetralin, potent and selective $5-\mathrm{HT}_{1 \mathrm{~A}}$ receptor agonists. Drug Dev. Res., 34, 66-85.

GLENNON, R.A., TITELER, M. \& MCKENNEY, J.D. (1984). Evidence for $5-\mathrm{HT}_{2}$ involvement in the mechanism of action of hallucinogenic agents. Life Sci., 35, 2505-2511.

GLENNON, R.A., TITELER, M. \& SANDERS-BUSH, E. (1992), Hallucinogens and serotonergic mechanisms. NIDA Res. Monograph, 119, $131-135$.

GOODWIN, G.M., DE SOUZA, R.J., GREEN, A.R. \& HEAL, D.J. (1987). The pharmacology of the behavioural and hypothermic responses of rats to 8-hydroxy-2(di-n-propylamino)tetralin (8-OHDPAT). Psychopharmacology, 91, 506-511.

HADRAVA, V., BLIER, P. \& DE MONTIGNY, C. (1996). Partial agonistic activity of R- and S-enantiomers of 8-OH-DPAT at 5$\mathrm{HT}_{1 \mathrm{~A}}$ receptors. J. Psychiatry Neurosci., 21, 101-108.

HAMON, M., COLLIN, E., CHANTREL, D., DAVAL, G., VERGE, D., BOURGOIN, S. \& CESSELIN, F. (1990). Serotonin receptors and the modulation of pain. In Serotonin and Pain, ed. Besson, J.M. pp. 53-72. Amsterdam: Excerpta Medica.

HARTIG, P.R., HOYER, D., HUMPHREY, P.P.A. \& MARTIN, G.R. (1996). Alignment of receptor nomenclature with the human genome: classification of $5-\mathrm{HT}_{1 \mathrm{~B}}$ and $5-\mathrm{HT}_{1 \mathrm{D}}$ receptor subtypes. TIPS, 17, $103-105$.

HIEBLE, J.P., BONDINELL, W.E. \& RUFFOLO, R.R.J. (1995). $\alpha$ - and $\beta$ adrenoceptors: from the gene to the clinic. 1. Molecular biology and adrenoceptor subclassification. J. Med. Chem., 38, 34153444

HJORTH, S. \& CARLSSON, A. (1986). Is pindolol a mixed agonistantagonist at central serotonin (5-HT) receptors? Eur. J. Pharmacol., 129, $131-138$.

HJORTH, S., CARLSSON, A., LINDBERG, P., SANCHEZ, D., WIKSTRÖM, H., ARVIDSSON, L.E., HACKSELL, U. \& NILSSON, J.L.G. (1982). 8-Hydroxy-2-(di-n-propylamino)tetralin, 8-OH-DPAT, a potent and selective simplified ergot congener with central 5-HT receptor stimulating activity. J. Neur. Transm., 55, 169-188.

HOYER, D., CLARKE, D.E., FOZARD, J.R., HARTIG, P.R., MARTIN, G.R., MYLECHARANE, E.J., SAXENA, P.R. \& HUMPHREY, P.P.A. (1994). VII. International Union of Pharmacology Classification of Receptors for 5-Hydroxytryptamine (Serotonin). Pharmacol. Rev., 46, $157-203$.

HOYER, D. ENGEL, G. \& KALKMAN, H.O. (1985). Molecular pharmacology of $5-\mathrm{HT}_{1}$ and $5-\mathrm{HT}_{2}$ recognition sites in rat and guinea-pig membranes: radioligand binding studies with $\left[{ }^{3} \mathrm{H}\right] 5$ HT, $\left[{ }^{3} \mathrm{H}\right] 8-\mathrm{OH}-D P A T,(-)\left[{ }^{125} \mathrm{I}\right]$ iodocyanopindolol, $\left[{ }^{3} \mathrm{H}\right]$ mesulergine and $\left[{ }^{3} \mathrm{H}\right]$ ketanserin. Eur. J. Pharmacol., 118, 13-23.

HOYER, D. \& MARTIN, G.R. (1997). 5-HT receptor classification: towards a harmonization with the human genome. Neuropharmacology, 36, 419-428.

JACKSON, D.M. BENGTSSON, A., JOHANSSON, C, CORTIZO, L. \& ROSS, S.B. (1994). Development of tolerance to 8-OH-DPAT induced blockade of acquisition of a passive avoidance response. Neuropharmacology, 33, 1003-1009.

JOHANSSON, C., ÖGREN, S.O. \& THORBERG, S.O. (1988). Drugs characterized as $5-\mathrm{HT}_{1}$ agonists affect passive avoidance in rats. Adv. Biosci., 70, $81-84$

KIRK, R.E. (1968). Experimental design: Procedures for the behavioural sciences, Belmonte: Brooks/Cole Publ. Comp.
KOE, B.K. \& WEISSMAN, A. (1966). p-Chlorophenylalanine: a specific depletor of brain serotonin. J. Pharmacol. Exp. Ther., 154, $499-$ 516.

LEJEUNE, F., NEWMAN-TANCREDI, A., AUDINOT, V. \& MILLAN, M.J. (1997). Interactions of (+)- and (-)-8- and 7-hydroxy-2-(di$\mathrm{n}$-propylamino)tetralin at human $(\mathrm{h}) \mathrm{D}_{3}, \mathrm{hD}_{2}$ and $\mathrm{h}$ serotonin $\mathrm{As}_{1 \mathrm{~A}}$ receptors and their modulation of the activity of serotoninergic and dopaminergic neurones in rats. J. Pharmacol. Exp. Ther., 280, $1241-1249$

LEYSEN, J.E., DE CHAFFOY DE CORCELLES, D., DE CLERCK, F., NIEMEGEERS, C.J.E. \& VAN NEUTEN, J.M. (1984). Serotonin-S receptor binding sites and functional correlates. Neuropharmacology, 23, $1492-1501$

LEYSEN, J.E., NIEMEGEERS, C.J.E., VAN NEUTEN, J.M. \& LADUR ON, P.M. (1982). Ketanserin (R41468), a selective ${ }^{3} \mathrm{H}$-ligand for

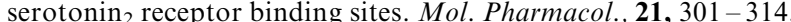

LIU, Y., YU, H., SVENSSON, B.E., CORTIZO, L., LEWANDER, T. \& HACKSELL, U. (1993). Derivatives of 2-(dipropylamino)tetralin: effect of the $\mathrm{C} 8$-substituent on the interaction with $5-\mathrm{HT}_{1 \mathrm{~A}}$ receptors. J. Med. Chem., 36, $4221-4229$.

MARTIN, L.L. \& SANDERS-BUSH, E. (1982). Comparison of the pharmacological characteristics of $5-\mathrm{HT}_{1}$ and $5-\mathrm{HT}_{2}$ binding sites with those of serotonin autoreceptors which modulate serotonin release. Naunyn-Schmiedeberg's Arch. Pharmacol., 321, $165-170$.

MARTIN, W.R. \& SLOAN, J.W. (1986). Relationship of CNS tryptaminergic processes and the action of LSD-like hallucinogens. Pharmacol. Biochem. Behav., 24, 393-399.

MIDDLEMISS, D.N. (1986). Blockade of the central 5-HT autoreceptor by $\beta$-adrenoreceptor antagonists. Eur. J. Pharmacol., 120, $51-56$.

MIDDLEMISS, D.N. \& FOZARD, J.R. (1983). 8-Hydroxy-2-(di-npropylamino)tetralin discriminates between subtypes of the 5$\mathrm{HT}_{1}$ recognition site. Eur. J. Pharmacol., 90, 151-153.

MIDDLEMISS, D.N., NEILL, J. \& TRICKLEBANK, M.D. (1985). Subtypes of the 5-HT receptor involved in hypothermia and forepaw treading induced by 8-OH-DPAT. Br. J. Pharmacol., 85, 251P

NAHORSKI, S.R. \& WILLCOCKS, A.L. (1983). Interactions of $\beta$ adrenoreceptor antagonists with 5-hydroxytryptamine receptor subtypes in rat cerebral cortex. Br. J. Pharmacol., 78, 107P.

NENONENE, E.K., RADJA, F., CARLI, M., GRONDIN, L. \& READER, T.A. (1994). Heterogeneity of cortical and hippocampal 5-HT $1 \mathrm{~A}$ receptors: a reappraisal of homogenate binding with $8-\left[{ }^{3} \mathrm{H}\right] \mathrm{Hy}-$ droxydipropylaminotetralin. J. Neurochem., 62, 1822-1834.

ÖGREN, S.O. (1982). Forebrain serotonin and avoidance learning: behavioural and biochemical studies on the acute effect of pchloroamphetamine on one-way active avoidance learning in the male rat. Pharmacol. Biochem. Behav. 16, 881-895.

ÖGREN, S.O. (1985a). Central serotonin neurones in avoidance learning: interactions with noradrenaline and dopamine neurones. Pharmacol. Biochem. Behav., 23, 107-123.

ÖGREN, S.O. (1985b). Evidence for a role of brain serotonergic neurotransmission in avoidance learning. Acta Physiol. Scand., 125 (suppl. 544), $1-71$

ÖGREN, S.O. (1986a). Analysis of the avoidance learning deficit induced by the serotonin releasing compound p-chloroamphetamine. Brain Res. Bull., 16, 645-660.

ÖGREN, S.O. (1986b). Serotonin receptor involvement in the avoidance learning deficit caused by p-chloroamphetamineinduced serotonin release. Acta Physiol. Scand., 126, 449-462.

ÖGREN, S.O., FUXE, K., ARCHER, T., JOHANSSON, G. \& HOLM, A.C. (1982). Behavioural and biochemical studies on the effects of acute and chronic administration of antidepressant drugs on central serotoninergic receptor mechanisms. Adv. Biosci., 40, $11-19$

OVERTON, D.A. (1966). State-dependent learning produced by depressant and atropine-like drugs. Psychopharmacologica (Berl), 10, 6-31.

PAWLOWSKI, L., PRZEGALINSKI, E. \& HANO, J. (1983). Antiserotonergic and antidopaminergic action of pirenperone, a new $\mathrm{S}_{2-}$ serotonin receptor antagonist. Naunyn-Schmiedeberg's Arch. Pharmacol., 324, 20R.

PEROUTKA, S.J. \& SNYDER, S.H. (1982). Recognition of multiple serotonin receptor binding sites. Adv. Biochem. Psychopharmacol., 34, 155-172.

RIEKKINEN, P.JR. (1994). 5-HT $1 \mathrm{~A}$ and muscarinic acetylcholine receptors jointly regulate passive avoidance behaviour. Eur. J. Pharmacol., 262, 77-90. 
ROUTLEDGE, C. (1996). Development of 5-HT $1 \mathrm{~A}$ receptor antagonists. Behav. Brain. Res., 73, $153-156$

RUAT, M., TRAIFFORT, E., LEURS, R., TARDIVEL-LACOMBE, J., DIAZ, J., ARRANG, J.M. \& SCHWARTZ, J.C. (1993). Molecular cloning, characterization, and localization of a high affinity serotonin receptor $\left(5-\mathrm{HT}_{7}\right)$ activating cAMP formation. Proc. Natl. Acad. Sci. U.S.A., 90, 8547-8551.

RUFFOLO, R.R.JR., BONDINELL, W. \& HIEBLE, J.P. (1995). $\alpha$ - and $\beta$ adrenoceptors: from the gene to the clinic. 2. Structure-activity relationships and therapeutic applications. J. Med. Chem., 38, $3681-3716$.

SANCHEZ, C., ARNT, J. \& MOLTZEN, E. (1996). Assessment of relative efficacies of 5- $\mathrm{HT}_{1 \mathrm{~A}}$ receptor ligands by means of in vivo animal models. Eur. J. Pharmacol., 315, 245-254.

SAXENA, P.R. (1995). Serotonin receptors: subtypes, functional responses and therapeutic relevance. Pharmac. Ther., 66, 339368

SCHREIBER, R. \& DE VRY, J. (1993). 5-HT 1 A receptor ligands in animal models of anxiety. Impulsivity and depression: multiple mechanisms of action? Prog. Neuro-Psychopharmacol. Biol. Psych., 17, 87- 104.

THORBERG, S.O., HALL, H., ÅKESSON, C., SVENSSON, K. \& NILSSON, J.L.G. (1987). Aminochromans: potent agonists at central dopamine and serotonin receptors. Acta Pharm. Suec., 24, $169-182$.
TITELER, M., HERRICK, K., LYON, R., MCKENNEY, J.D. \& GLENNON, R.A. (1985). $\left[{ }^{3}\right.$ H]DOB: A specific agonist radioligand for 5- $\mathrm{HT}_{2}$ serotonin receptors. Eur. J. Pharmacol., 117, 145-146.

TITELER, M. \& LYON, R.A. (1987). Selectivity of serotonergic drugs for multiple brain serotonin receptors. Role of $\left[{ }^{3} \mathrm{H}\right]-4$-bromo-2,5dimethoxyphenylisopropylamine $\left(\left[{ }^{3} \mathrm{H}\right] \mathrm{DOB}\right)$, a $5-\mathrm{HT}_{2}$ agonist radioligand. Biochem. Pharmacol., 36, 3265-3271.

TRICKLEBANK, M.D., FORLER, C. \& FOZARD, J.R. (1984). The involvement of subtypes of the $5-\mathrm{HT}_{1 \mathrm{~A}}$ receptor and catecholaminergic system in the behavioural response to 8-hydroxy-2-(din-propylamino)tetralin in the rat. Eur. J. Pharmacol., 106, $271-$ 282 .

VILLALON, C.M. \& TERRON, J.A. (1995). 5-Hydroxytryptamine: considerations about discovery, receptor classification and relevance to medical research. Arch. Med. Res., 26, 331-344.

YU, H. LIU, Y, HACKSELL, U \& LEWANDER, T. (1993). (R)- and (S)-8-Acetyl-2-(dipropylamino)tetralin (LY-41): two novel 5$\mathrm{HT}_{1 \mathrm{~A}}$ receptor agonists. Eur. J. Pharmacol., 231, 69-76.

YU, H., LIU, Y., MALMBERG, A., MOHELL, N., HACKSELL, U. \& LEWANDER, T. (1996). Differential serotoninergic and dopaminergic activities of the (R)- and (S)-enantiomers of 2-(di-npropylamino)tetralin. Eur. J. Pharmacol., 303, 151-162.

(Received December 9, 1997 Revised June 19, 1998 Accepted July 1, 1998) 